\title{
OPPORTUNITES AND BARRIERS TO SUSTAINABLE URBAN DEVELOPMENT: AN ANALYSIS OF THE TORONTO GREEN STANDARD (VERSION 3)
}

\author{
By \\ Ross Edwards \\ BSc, McMaster University, 2018 \\ A Major Research Paper \\ presented to Ryerson University \\ in partial fulfillment of the requirements for the degree of \\ Master of Planning \\ in \\ Urban Development \\ Toronto, Ontario, Canada, 2020 \\ (C) Ross Edwards, 2020
}




\section{AUTHOR'S DECLARATION}

I hereby declare that I am the sole author of this MRP. This is a true copy of the MRP, including any required final revisions.

I authorize Ryerson University to lend this MRP to other institutions or individuals for the purpose of scholarly research.

I further authorize Ryerson University to reproduce this MRP by photocopying or by other means, in total or in part, at the request of other institutions or individuals for the purpose of scholarly research.

I understand that my MRP may be made electronically available to the public. 
OPPORTUNITES AND BARRIERS TO SUSTAINABLE URBAN DEVELOPMENT: AN ANALYSIS OF THE TORONTO GREEN STANDARD (VERSION 3)

\author{
CRoss Edwards 2020 \\ Master of Planning in \\ Urban Development Ryerson University
}

\begin{abstract}
The City of Toronto has pushed for sustainable development as a normative goal through the creation of the 'Toronto Green Standard' (TGS). The TGS requires all developments in the municipal boundary to meet a specified level of sustainability requirements. Since 2018 , the TGS has provided the opportunity to reach three voluntary tiers beyond the required tier (tiers 2-4), further enhancing sustainable building performance in exchange for a development charge refund. This report aims to determine the development characteristics most associated with Tier 2+. Results indicate that Tier 2+ developments are typically large-scale and mixed-use but vary given geographic context and developer characteristics. Moreover, results suggest that the development charge refund may not be a sufficient incentive for most developers, indicating a need for incentive reform. This research is a significant case study for planners considering the challenges and opportunities of encouraging sustainability in urban development.
\end{abstract}

Key Words: Sustainable Development, Resilience, Toronto Green Standard, Incentives 


\section{Acknowledgements}

I would like to acknowledge the emotional and educational support provided by my family. I would also like to thank all the faculty at Ryerson's Master of Planning in Urban Development program for their support, in particular, Nina-Marie Lister for encouraging me to pursue this research topic, refining my research process throughout, and providing tremendous feedback. Finally, I want to thank Lisa King of the City of Toronto for providing me with crucial knowledge about the Toronto Green Standard and for reviewing this report. 


\section{List of Figures and Tables}

Figure 1. Contemporary interpretations of ecological systems describe how disturbances can result in an alternative stable, some of which are more desirable than others. In this context, resilience is defined as the capacity of an ecosystem to return to a desired alternative stable state (Ghazoul et al., 2015). (Page 8)

Figure 2. In 2017, FLAP (Fatal Light Awareness Program) volunteers displayed the birds killed as result of window collisions (between January and April 2017) at the Royal Ontario Museum (Barrett, 2017). (Page 12)

Figure 3. Page one of the TGS checklist (Version 3) shows where developers must indicate the performance level they are targeting, where Tier 1 is required and Tiers 2 through 4 are voluntary with financial incentive. (Page 17)

Figure 4. Location of developments by TGS Tier targeted in the Toronto region. Black dots indicate Tier 2+ developments and white dots indicate Tier 1 developments. (Page 24)

Figure 5. Land use typology breakdown by Version 3 Tier targeted for Toronto developments May 2018 to December 2019. (Page 25)

Figure 6. Proportion of affordable housing component for Toronto developments May 2018 to December 2019. (Page 27)

Figure 7. Average number of storeys (maximum) for Toronto developments May 2018 to December 2019. (Page 27)

Figure 8. Average number of residential units (where applicable) for Toronto developments May 2018 to December 2019. (Page 27)

Figure 9. Average gross floor area for Toronto developments May 2018 to December 2019. (Page 28)

Figure 10. Location of Developer Headquarters (Head Office) for Toronto developments May 2018 to December 2019. (Page 29-30)

Figure 11. The area served by developers for Toronto developments May 2018 to December 2019. (Page 30)

Table 1. Total Energy Use Intensity (measured in eKWh/ $\mathrm{m}^{2}$ ) for buildings by Tier achieved (table modified from ZEBF Report) (City of Toronto, 2018b; King et al., 2018). (Page 18-19)

Table 2. Greenhouse Gas Intensity (measured in $\mathrm{kgCO} e / \mathrm{m}^{2}$ ) for buildings by Tier achieved (table modified from ZEBF Report) (City of Toronto, 2018b; King et al., 2018). (Page 19)

Table 3: The total percent change in construction costs associated with the lowest cost strategy for reaching each Tier, not including DC refunds (table adapted from ZEBF Report) (King et al., 2018). (Page 20)

Table 4. Development characteristic comparisons for 533 King St and 145 Wellington St. (Page 32-33)

Table 5. Development characteristic comparisons for 80 Dale Ave and 4097 Lawrence Ave E. (Page 34-35)

Table 6. Development characteristic comparisons for 300 Bloor St West and 95 St Joseph St. (Page 36-37)

Table 7. Development characteristic comparisons for 563 Gerrard St and 10 Gamble Ave. (Page 38-39) 


\section{Table of Contents}

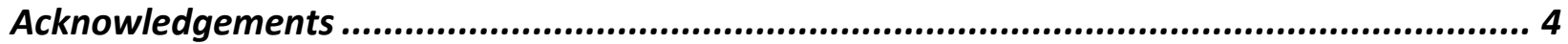

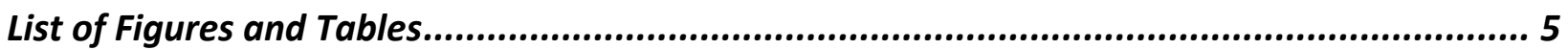

Introduction: Theorizing Sustainable Development................................................................... 7

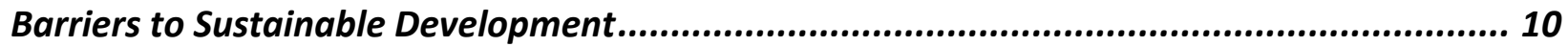

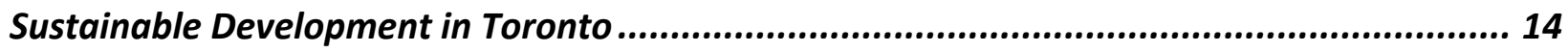

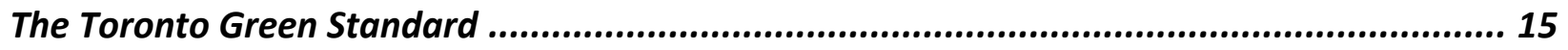

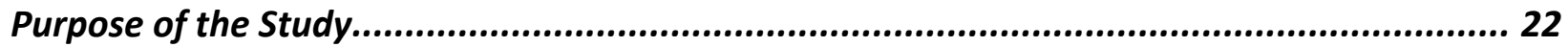

Part 1: General Characteristics Analysis ............................................................................... 22

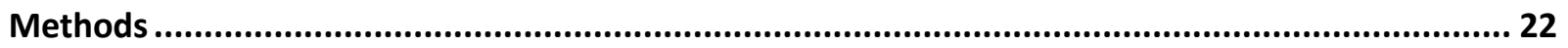

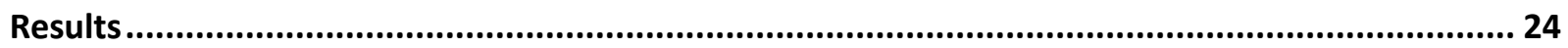

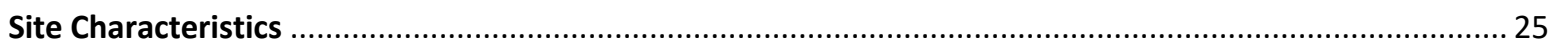

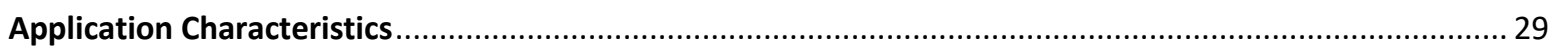

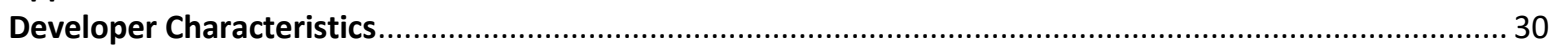

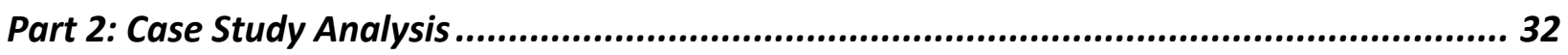

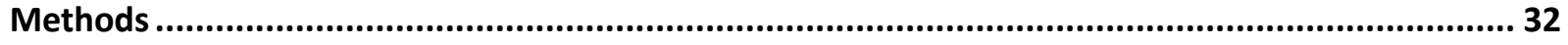

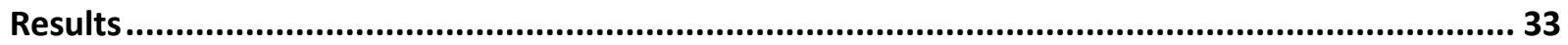

Case Study 1: 533 King Street West \& 145 Wellington St West ........................................................... 33

Case Study 2: 80 Dale Avenue and 4097 Lawrence Avenue East ......................................................... 36

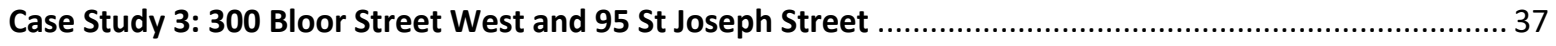

Case Study 4: 563 Gerrard Street and 10 Gamble Avenue ................................................................... 39

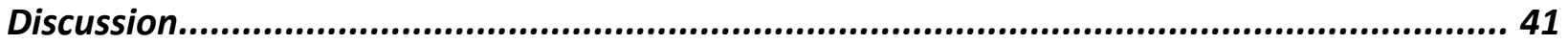

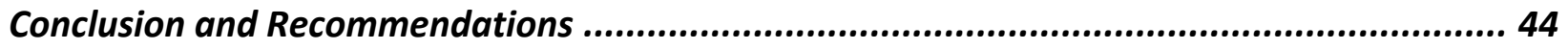

Future Research Directions and Considerations ................................................................ 45

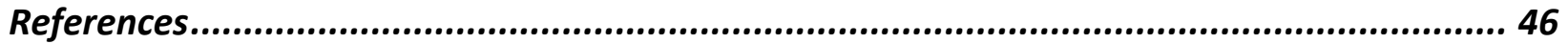

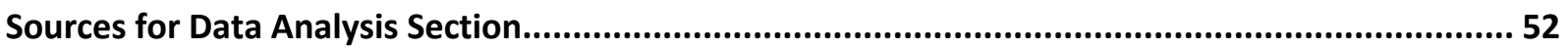




\section{Introduction: Theorizing Sustainable Development}

Over the past several decades, 'sustainable development' has become a normative focus for the planning discipline (Dale et al., 2012; Maclaren, 1996). Broadly speaking, sustainable development can be defined as the construction, operation, and maintenance of the urban form through sustainable means (Robert et al., 2012; Ahmadi \& Toghyani, 2012; Dale \& Robinson, 2012). This being said, 'sustainability' is a word that takes on the cultural hues of its era and has consequently taken on many meanings over the past century. Early interpretations in the 1980s were concerned primarily with sustainability as a kind of ideal harmony; the balancing of a three-pronged scale with 'economy', 'ecology', and 'society' strategically offsetting each other (Dale et al., 2012). This was replaced in the 2000s by a shift towards thirdgeneration sustainability, characterized by holistic systems-thinking, policy alignment, and legitimate community empowerment (Dale et al., 2012). A similar shift was evident in the ecological sciences, which originally took sustainability as the maintenance of a predictable system analogous to a well-oiled machine where all living things could be balanced perfectly through appropriate adjustments. This changed slowly over the past 70 years, in which the term 'ecosystem' gradually became to be understood as a complex, flexible, and unpredictable system with many possible semi-stable realities (Reed \& Lister, 2014). Moreover, defining the 'ecosystem' has broadened outward from a naive sense of 'natural' in which humans are passive observers to a definition that includes people and their creations as agents within a holistic system (Reed \& Lister, 2014). In this way, ecology has expanded into the broader discourse on urban sustainability while urban policy has begun to incorporate ecological epistemologies. In reality, there is no three-legged stool of 'economy', 'society', and 'ecology', but rather, a complex and unified system where the economy is emergent from society, and society is emergent from the biophysical system (Giddings et al., 2012). In this holistic view, sustainability can be defined as a complex system's state, in which the system returns to a previously stable state or transitions into an alternative stable state without annihilating itself in the process (Ben-Eli, 2018; Gunderson, 2000). From this definition, resilience generally refers to the capacity of a system to return to a particular stable state (Figure 1) (Gunderson, 2000; 
Ghazoul et al., 2015; Pickett et al. 2004). Note, however, that not all possible stable states would be particularly desirable for humans, only those with the capacity to support human life. In this way, our definitions of sustainability and resilience are usually framed anthropogenically - the goal is to sustain a system that we can live in. Climate change is an existential threat because it threatens to disturb ecological systems into alternative stable states unable to support human communities. Thus, cities can become sustainable insofar as they maintain stable states that allow human communities to flourish.

(A)

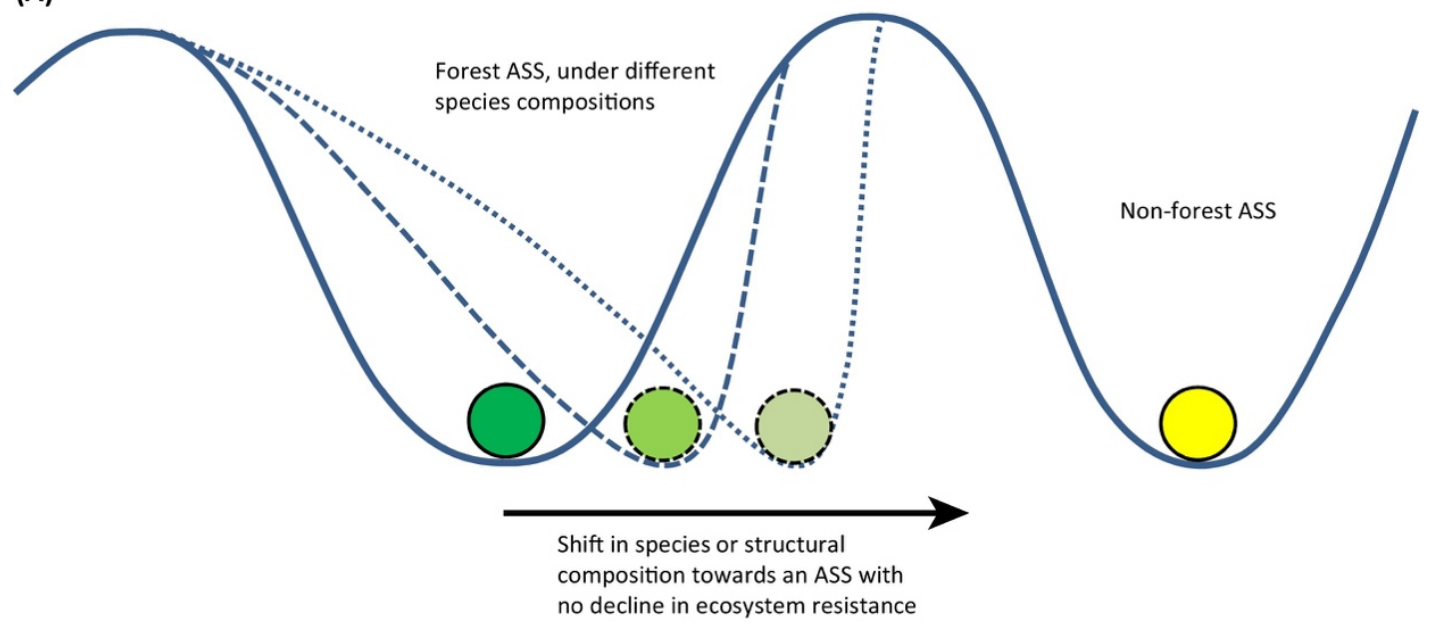

(B)

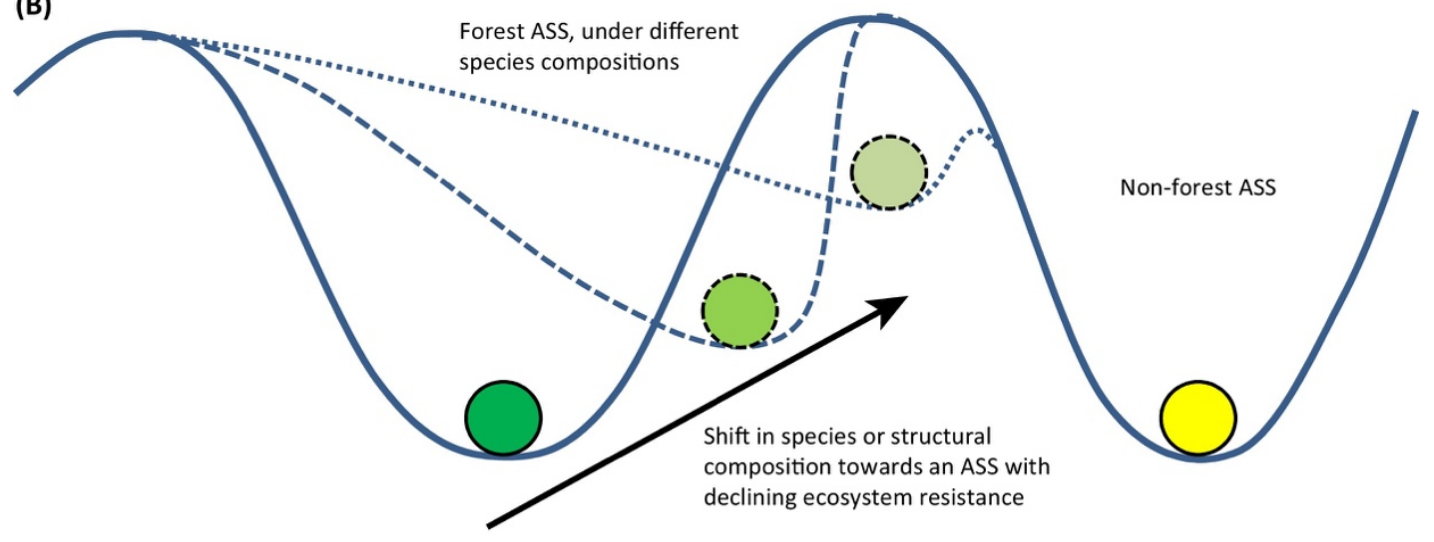

Trends in Ecology \& Evolution

Figure 1. Contemporary interpretations of ecological systems describe how disturbances can result in an alternative stable state (ASS), some of which are more desirable than others. In this 
context, resilience is defined as the capacity of an ecosystem to return to a desired alternative stable state (Ghazoul et al., 2015).

While sustainability is best defined as a system state, another common definition is as a normative ideal concerning meaningful change in the creation of more resilient communities (Mieg and Töpfer, 2013). To avoid misinterpretation, this paper will differentiate between 'sustainability' as a system state (Maclaren, 1996), and 'sustainable' as an adjective for the normative behaviours or tools that attempt to push the overall system towards sustainability. 'Sustainable technology' then refers to any technology with the capacity to enhance resilience in its local system, for example, energy-saving technology, which enhances urban resilience insofar as it reduces the emission of greenhouse gases.

Sustainable behaviour can take any number of forms, as long as the consequences of such behaviours establish resilience. Economically, change could occur through investment in sustainable technology, and socially, change could involve policy implementation that improves public education of climate change and ecological resilience (Ahmadi \& Toghyani, 2012). What is common among all such examples is that they are inherently about collective behaviour change, either limiting or encouraging human behaviour. As such, sustainable development (meaning development that enhances the resilience of its local system; a subset of sustainable technology) is chiefly concerned with the collective behavioural change of developers, current residents, and potential residents. The aim of regulation is to limit behaviour involved with the construction, operation, and maintenance that is considered unsustainable (a negative driver), and the aim of incentivization is to encourage any such behaviour considered sustainable (a positive driver). However, behavioural change is impeded by barriers resulting from various sources of resistance. 


\section{Barriers to Sustainable Development}

According to pluralist theory, barriers to sustainable development emerge as a manifestation of interest groups in opposition to the ideals of sustainability, all within a political system defined by interest groups vying for power (Hartmann, 1999; Brown, 2008). Moreover, the political system is where collective aims are determined and where policies and regulations will be created that will restrict or open behavioural opportunities. Thus, the opposition to sustainable development means primarily an opposition to development regulations, whether acting as an individual or as an interest group (Hartmann, 1999).

The interest group most obviously affected by sustainable development is the development industry. Given that the attitude of perpetual economic growth is ingrained in the business culture of the industrialized world (Barry, 2018), the optimization of profit through investment in development is expected to be the motivating factor for all developers. Without this motivation, the logic of economics suggests that a developer would not stay competitive and could no longer 'play the game' at all. It follows that developers will avoid sustainable building components as an additional cost without (1) economic incentive, or (2) greater consumer demand.

Globally, there are countless incentive programs available for developers in exchange for sustainable development. Many of the programs are initiated by local governments, in which developers are offered financial incentives or structural incentives. In this context, financial incentives refer to any incentive that provides direct financial benefit to the developer, such as property tax refunds or grants (Shazmin et al., 2017; USGBC, 2014). Structural incentives then refer to any incentive that provides indirect benefit through additional or faster permissions granted by the development approval body, such as density and height bonuses or expedited processing (NAIOP, 2007; USGBC, 2014). 
Other programs are initiated by the private sector, such as LEED (Leadership in Energy and Environmental Design) or BOMA (Building Owners and Manager Association), under the promise of energy savings (reduced operation costs) and increased consumer demand (Fuerst, 2009). This is true whether or not the resulting building is entirely ecologically sustainable. For example, LEED has been under scrutiny for marketing certified LEED buildings as 'green', while their local ecological impact can be negative (Ogden, 2014). This is likely because LEED is designed such that builders can effectively choose the subcategories they would like to focus on (which vary in environmental benefit) in order to achieve certification, resulting in buildings with the same LEED score having very different environmental impacts (Wedding \& CrawfordBrown, 2008). Consequently, developers are likely to choose subcategories with the lowest possible cost, and exclude other important subcategories, such as mitigating bird fatalities through window glazing. Indeed, there is evidence that energy-efficient window glazing on LEED buildings has contributed to bird deaths via window collisions (Figure 2) (Ogden, 2014). 


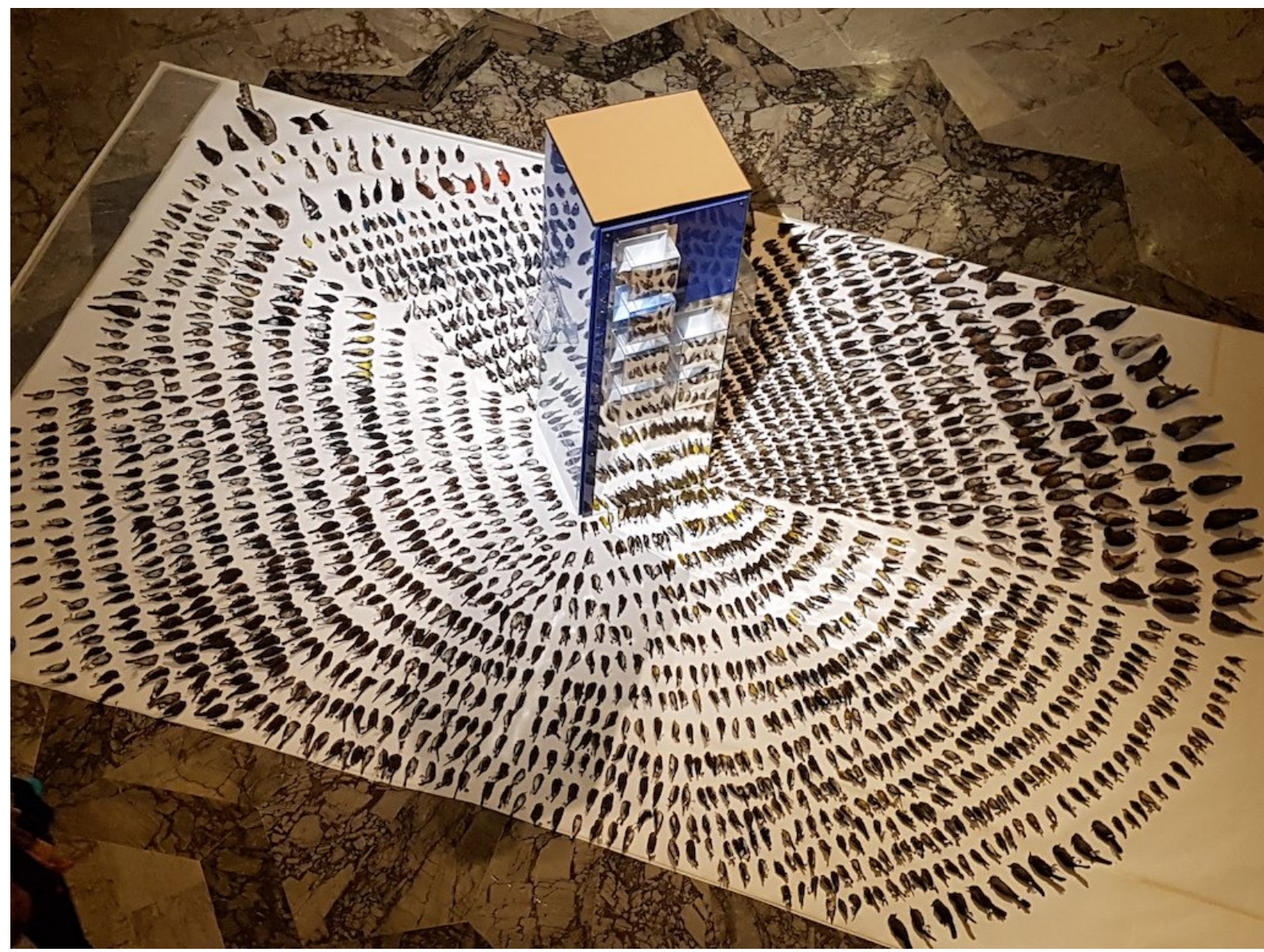

Figure 2. In 2017, FLAP (Fatal Light Awareness Program) volunteers displayed the birds killed as result of window collisions (between January and April 2017) at the Royal Ontario Museum (Barrett, 2017).

Typically, sustainable building components with high ROI (return on investment) potential (such as energy-saving technology) can be successfully marketed by the private sector, whereas components with less ROI potential will require significant state-imposed incentive schemes. For example, intensive green roofs have much higher installation and maintenance fees than extensive green roofs (22-43\% higher cost), with little obvious return on investment, meaning their existence likely hinges on attractive incentive mechanisms (Banting et al., 2005). The only other way for these components to be supplied by the private sector is through significant consumer demand. And while demand appears to be growing in Canada (CaCBG, 2014), it is often limited by the 'values-action gap': the gap between a consumer's expressed value 
towards sustainable goals and the evidence of their actual behaviour (Young et al., 2009; Chapin \& Wyton, 2014).

More crucially, the increasing inequality in most urban centers globally (Florida, 2017) suggests that even if consumers value sustainable development, they may be financially limited to buy or rent property with a cost premium resulting from sustainable building components. In this way, sustainable development and green architecture have been commodified (Lee, 2011). And because it is only the optics of sustainability that is the commodity, developers ostensibly have no economic incentive to concern themselves with sustainable components that are neither financially rewarding nor in demand. In understanding this point, it is useful to consider the distinction between biophilia and sustainability. Biophilia is defined originally by the ecologist E.O. Wilson as an instinctual drive to associate with other organisms (1984). It is a deeply personal and psychological behaviour that is based on a qualitative feeling towards the natural environment (Wilson, 1984). On the other hand, sustainability is a characteristic of a complex system in which it maintains some form of ever-changing stability, usually the capacity to remain within a desired alternative stable state (Ben-Eli, 2018; Ghazoul et al., 2015). It is neither personal nor psychological, because it applies to an entire system and not an individual. In follows that there are some aspects of a system (those that go unnoticed or are unknown by most consumers) that do not create any biophilic effect but are nevertheless crucial for the system's sustainability. For example, window glazing that protects against bird collisions might not be appreciated by condominium consumers because its effect is not immediately visible (there is no direct biophilic effect received from living in the unit). Because of this, consumers' motivation for paying a cost premium as a result of this technology must be based on their motivation to protect the local ecosystem. While this may be the case for some consumers, the values-action gap suggests that many people will lack either the motivation or the financial capacity, thus limiting demand from the perspective of developers (Young et al., 2009; Chapin \& Wyton, 2014). 
Sustainable development incentive programs are further limited by financial risk. From the developers' perspective, risks can accrue from vacancies due to unforeseen lack of consumer interest (i.e. demand) or technological changes resulting in competition from developers with more efficient energy saving technology. Risk can also accrue from larger, more complex developments, which may be more likely to undergo complex planning processes (Runde \& Thorne, 2017). From a tenant's perspective, their rental agreement may lock them into a fixed cost, which has risk if new opportunities (resulting from more efficient technology) arise, or if demand decreases overall (lowering costs of similar units) (Runde \& Thorne, 2017).

Not surprisingly, the default behaviour of the development industry is to continue the construction of buildings that lack sustainable components with some exceptions (Conte, 2018; Turner, 2017; Winfield, 2003). This traditional type of development is low-risk and developers can apply their experience to it more readily, as compared with the somewhat novel approaches needed for sustainable development (Winfield, 2003). Consequently, it is within developers' financial interest to prevent significant policy agendas with sustainable ideals from materializing into concrete legislation, at least without worthwhile incentives.

\section{Sustainable Development in Toronto}

The focus of this research paper will be on sustainable development in Toronto, Canada. Contextually, it's important to note that the City exists in the context of an ever-growing housing crisis and considerable income inequality between residents, which has resulted geographic divisions based on relative socioeconomics (Florida, 2017; Hulchanski, 2019). This was most famously articulated by Hulchanski, who created the 'three cities' model of Toronto, which interpreted the City as split into three socioeconomic classes. His model shows how overtime the middle class has mostly disappeared, while income inequality has increased dramatically (2019). Since sustainable development is known to come with a cost premium (Russ et al., 2018), the model suggests that this cost premium would prevent equitable access of sustainable development in an already divided city. 
Despite the economic challenges, environmental interest groups in Toronto have long advocated for the normative pursuit of sustainable development ideals in a way that is equitable (Hartmann, 1999). This movement began in the 1960s, coinciding with a broader leftist urban political reformation established by Jane Jacobs, David Crombie, and John Sewell, among others (Hartmann, 1999; Boudreau, 2006). Since this era, Ontario legislation has incorporated some of the objectives of sustainable development ideals that have had deep effects on Toronto. In particular, development in the province of Ontario is governed by the Planning Act (1990), and the Provincial Policy Statement (2014). Both of these documents include statements indicating the Province's interest in broad topics including "the protection of ecological systems, including natural areas, features, and functions." and "the orderly development of safe and healthy communities." (Planning Act, S. 2), values meant to express a vague but desired collective concern for sustainable goals. And since climate change mitigation has become a categorical necessity of resilience, the Province has included it as a separate interest: "the mitigation of greenhouse gas emissions" (Planning Act, S. 2).

At the municipal level of Toronto, these broad interests appear to have manifested in specific regulatory tools. The remainder of this paper will focus on one such regulatory tool for its considerable power to change decision-making in Toronto's development sector on a large scale: the Toronto Green Standard (TGS).

\section{The Toronto Green Standard}

The TGS is a municipal tool that was created to ensure a level of sustainable design (higher than conventional standards) in all buildings within the city's boundary. It involves both a regulatory component, including a series of sustainable design requirements that must be abided in order for the application to be approved, as well as an incentive component in the form of a development charge (DC) refund for reaching a level of sustainable design (Tier 2 to Tier 4) above what is minimally required (City of Toronto, 2017). The TGS is distinct from other green 
building programs in at least two fundamental ways. First, its Tier 1 sustainability requirements apply to all developments, unlike voluntary standards such as LEED. Second, tiers are reached only through the achievement of measures in all subcategories related to sustainability: Air Quality; Energy Efficiency; Greenhouse Gas (GHG) and Resilience; Water Balance, Quality, and Efficiency; Ecology; and Solid Waste (City of Toronto, 2017). Unlike LEED, developments cannot achieve sustainability requirements by focusing only on the most cost-efficient components, such as energy saving technology. Rather, developments must include sustainable components with both high and low potential ROls (City of Toronto, 2019).

The current version of the TGS is Version 3, with three checklists designed for Low-Rise Residential development; Mid to High-Rise Residential and Non-Residential development; and City Agency, Corporation, and Division-Owned facilities. Low-Rise residential developments, and Mid to High-Rise Residential and Non-Residential developments must meet a minimum of Tier 1, with Tier 2 to 4 being voluntary (Figure 3), whereas the City Agency, Corporation, and Division-Owned facilities must meet all Tier 1 and 2 requirements for projects greater than 100 meters GFA (City of Toronto 2017; 2020). 
Checklist - Toronto Green Standards Version 3.0

Complete in conjunction with the full Toronto Green Standard Version 3.0 (TGS V3.0) and Specifications.

Tier 1 performance measures are required by the City and must be included as part of your approved development application.

Tier 2, 3 and 4 higher performance levels are voluntary and are associated with financial incentives. To determine eligibility for incentives go to www.toronto.ca/greendevelopment.

Performance Level: $\square$ Tier 1 (Required) $\quad \square$ Tier $2 \quad \square$ Tier $3 \quad \square$ Tier 4

Application Information:

$\square$ Site Plan Control $\quad \square$ Zoning Bylaw Amendment $\quad \square$ Draft Plan of Subdivision

Application Number: $\quad$ Date Received (yyyy-mm-dd):

Community Planner (First, Last Name):

Is this checklist revised from an earlier submission? $\square$ Yes $\square$ No

Gross Floor Area $\left(\mathrm{m}^{2}\right)$ : $\quad$ Number of Storeys: Number of Units:

Non Residential Gross Floor Area $\left(\mathrm{m}^{2}\right)$ :

Proposal Description: (Include a narrative of your project highlighting green attributes or performances measures)

Property and Applicant Information

Address of Subject Land (Street Number and Name):

Project Name:

Applicant/Agent

Name (First, Last Name)

Business Telephone Number:

Business Email: Registered Owner (First, Last Name):

$11-00622018-05$

Figure 3. Page one of the TGS checklist (Version 3) shows where developers must indicate the performance level they are targeting, where Tier 1 is required and Tiers 2 through 4 are voluntary with financial incentive (DC Refund).

Version 3 has evolved significantly from its first several versions. The TGS was initiated as a voluntary green standard in 2006 for all new development and became a mandatory step in the development approval process in 2010 involving two-tiers: a mandatory list of performance metrics (Tier 1 ) and a voluntary list of performance metrics (Tier 2 ) in exchange for financial incentives. It was then revised in 2013 to create 'Version 2', and then again in 2018 to create 'Version 3' with added metrics and two additional tiers (Tier 3 and 4) (City of Toronto, 2017). Since then, modest revisions on performance measures have taken place intermittently, as passed by City Council. In particular, the TGS updated in January 2018 to include an 'Energy 
Strategy' applying to all developments with a total GFA of 20,000 SF or greater or developments with a City-approved 'Community Energy Plan'. Effectively, the Energy Strategy requires developers to monitor their energy consumption and carbon output and recommend opportunities for the use of sustainable technology (City of Toronto, 2018a).

From the beginning, the TGS was designed in accordance the with City's larger aim of creating a healthy and prosperous City, and to reduce GHG emissions in the municipality by $80 \%$ of 1990 levels in 2050 (City of Toronto, 2017). In order to reach this goal, the Atmospheric Fund and the City of Toronto developed the Zero Emissions Building Framework (ZEBF) in 2017. The ZEBF recommended a phased approach to the TGS, making Tier 2 required in 2022, Tier 3 required in 2026, and Tier 4 required in 2030 (King et al., 2018). Though not yet approved by council, this plan could help gradually phase in greater and greater sustainability requirements. In doing so, the TGS is meant to raise expectations for developers in a gradual way, demonstrating a new norm for development in Toronto (King et al., 2018; City of Toronto, 2017). The ZEBF also emphasized performance-based metrics, recommending that the TGS focus on the performance of buildings rather than the installation of individual components. This was integrated into Version 3 of the TGS in a number of ways, for example, by permitting Passive House certification and CaGBC Zero Carbon Building Standard, which are accepted as a performance measures for Tier 3 or 4 (King et al., 2018). Both passive houses and zero carbon buildings imply a commitment to low energy consumption. When applied to the TGS, this means a significant reduction in energy use intensity (measured in equivalent Kilowatt Hours per meter squared, or, ekWh/m²) (Table 1) and greenhouse gas intensity (Table 2).

\begin{tabular}{|l|l|l|l|l|}
\hline Building Type & Tier $\mathbf{1}$ & Tier $\mathbf{2}$ & Tier 3 & Tier 4 \\
\hline MURB (5+ storeys) & 170 & 135 & 100 & 75 \\
\hline $\begin{array}{l}\text { MURB (5+ storeys, } \\
\text { woodframe) }\end{array}$ & 165 & 130 & 100 & 70 \\
\hline Commercial Office & 175 & 130 & 100 & 65 \\
\hline Commercial Retail & 170 & 120 & 90 & 60 \\
\hline $\begin{array}{l}\text { Mixed-use (90\% res., 5\% } \\
\text { retail, 5\% commercial) }\end{array}$ & 170 & 134 & 100 & 74 \\
\hline
\end{tabular}


Table 1. Total Energy Use Intensity (measured in eKWh/ $\mathrm{m}^{2}$ ) for buildings by Tier achieved (table modified from ZEBF Report) (City of Toronto, 2018b; King et al., 2018). MURB refers to 'MultiUnit Residential Building'.

\begin{tabular}{|l|l|l|l|l|}
\hline Building Type & Tier 1 & Tier 2 & Tier 3 & Tier 4 \\
\hline MURB (5+ storeys) & 20 & 15 & 10 & 5 \\
\hline $\begin{array}{l}\text { MURB (5+ storeys, } \\
\text { woodframe) }\end{array}$ & 20 & 15 & 10 & 5 \\
\hline Commercial Office & 20 & 15 & 8 & 4 \\
\hline Commercial Retail & 20 & 15 & 5 & 3 \\
\hline $\begin{array}{l}\text { Mixed-use (90\% res., 5\% } \\
\text { retail, 5\% commercial) }\end{array}$ & 20 & 15 & 10 & 5 \\
\hline
\end{tabular}

Table 2. Greenhouse Gas Intensity (measured in $\mathrm{kgCO} 2 \mathrm{e} / \mathrm{m}^{2}$ ) for buildings by Tier achieved (table modified from ZEBF Report) (City of Toronto, 2018b; King et al., 2018).

As of 2017, the benefit of Tier 1 and Tier 2 developments as compared to conventional building code standards was estimated to be a reduction of 115,205 tonnes of carbon dioxide equivalent (CO2e) (City of Toronto, 2017). TGS preventative measures against bird collisions were also featured as a 'best practice' in 2016 for Toronto development (City of Toronto, 2018d). Presumably, these design features have saved many migratory birds, since several thousands are killed via building collisions due to poor window design each year (4,934 in 2010) (Cusa et al., 2015). Other performance indicators are more difficult to measure, but the TGS is expected to have contributed positively to air quality, water quality, sustaining urban pollinators, solid waste reduction, the tree canopy, plant biodiversity, protecting natural heritage, and reducing light pollution (being the categories the performance measures are most concerned with) (City of Toronto, 2017).

While the development sector has adapted to TGS requirements so far, the added construction cost to developments is significant for higher tiers (King et al., 2018). In comparison to a 
baseline of TGS Version 2 Tier 1, the cost premiums as a result of energy-saving technology are shown in Table 3 below.

\begin{tabular}{|l|l|l|l|l|}
\hline Building Type & Tier 1 & Tier 2 & Tier 3 & Tier 4 \\
\hline High-Rise MURB & $1.5 \%$ & $3.5 \%$ & $6.0 \%$ & $3.6 \%$ \\
\hline Low-Rise MURB & $0.5 \%$ & $2.1 \%$ & $5.1 \%$ & $4.9 \%$ \\
\hline Commercial Office & $2.3 \%$ & $3.1 \%$ & $3.0 \%$ & $2.2 \%$ \\
\hline Commercial Retail & $0.7 \%$ & $6.5 \%$ & $8.2 \%$ & $16.9 \%$ \\
\hline
\end{tabular}

Table 3: The total percent change in construction costs associated with the lowest cost strategy for reaching each Tier, not including DC refunds (table adapted from ZEBF Report) (King et al., 2018). According to the ZEBF, the higher premiums for commercial retail space is attributable to its relatively lower cost per square foot of floorspace as compared to residential and office space (King et al., 2018). Notice also that (with the exception of commercial retail) Tier 4 cost premiums are lower than Tier 3, a phenomenon caused by the elimination of construction costs associated with the higher efficiency involved in construction (King et al., 2018).

To encourage developers to reach tiers beyond Tier 1, a partial DC refund is offered by the City of Toronto. Eligibility for this program is evaluated by third parties registered with the City of Toronto (City of Toronto, 2020b). As of November 2019, by-law 515-2018 (Development Charges By-law) indicates that the refund is calculated based on the following formulas:

For Non-residential buildings (GFA in square meters):

DC Refund = (Non-residential ground floor GFA $) *(\$ 36.88$ Cap Amount $)$

For Residential buildings:

DC Refund = (Number of Residential Units of Type X)*(Cap Amount determined for Type X) 
Where Type X can be single detached and semi-detached (Cap =\$4,999); Apartment: two bedroom and larger (Cap $=\$ 3,190)$; Apartment: one bedroom and bachelor (Cap $=\$ 2,176)$; Multiple (all multiples) (Cap $=\$ 4,054)$; or Dwelling room (Cap $=\$ 1,350)$ (City of Toronto, 2019b). Currently, the DC refund applies similarly for Tiers 2, 3, and 4, and are designed to cover the up-front cost premium associated with sustainable components. However, an updated cost-benefit analysis has found that the cost premium increase that has resulted from new performance targets for Version 3 has made the DC refund program less of an incentive as it did in the past. Indeed, a Version 3 (Tier 2) DC refund was estimated to cover $23 \%$ of the initial energy-related cost premium, whereas it covered 52\% for Version 2 (Tier 2) (King et al., 2018; City of Toronto, 2018c). Additionally, a lifecycle cost analysis suggests that while high-rise MURBs, low-rise MURBs, and commercial office buildings will result in cost savings over 25 years for Tier 2 (Version 3), commercial retail will ultimately lose money on the investment (King et al., 2018). And in order for long-term cost savings to be seen as an incentive, developers must continue to own the building post-construction, which is not always the case.

This has triggered an exploration of other incentive schemes, such as grants, cap and trade, expedient processing, and fee reductions (City of Toronto, 2018c; King et al., 2018). Other possible schemes include a 'feebate' system, which charge underperforming buildings and use the levies to refund high performing buildings (creating both a push and pull factor), and lowinterest loan programs (King et al., 2018). The need for better incentives was reiterated in a consultation meeting with BILD (Building Industry and Land Development Association) (City of Toronto, 2017; City of Toronto 2020). Still, the TGS Version 3 has the benefit of applying standards to all Toronto development, making the development process more predictable and therefore, reducing risk. In this way, the TGS has considerable potential to change sustainable development norms. 


\section{Purpose of the Study}

The TGS provides an opportunity for studying the barriers and opportunities of sustainable development. Due to the nature of its tier system, developments can be distinguished by achieving minimal standards (Tier 1 ) or achieving standards beyond expectations (Tier 2 to 4 ). The purpose of this study is to determine the key differences between these two types of developments (Tier 1 and Tier $2+$ ) in order to determine the contextual factors that allow developments to reach/target as high a level of sustainability as possible. These contextual factors include the characteristics of the developers, the sites, the development type, and the application process. In order to consider the most recent development activity possible, this study analyzes Version 3 developments from May 2018 to the end of December 2019. In doing so, this report aims to address the current barriers and opportunities to sustainable development in Toronto and offer potential recommendations for addressing barriers.

\section{Part 1: General Characteristics Analysis}

\section{Methods}

Data was collected between September 2019 and January 2020 from two sources: The City of Toronto public database on Development Applications and internal datasets used by TGS staff. All data collection was limited to these secondary sources due to the time limitations of this project, as well as the scope of the project being centered on high-level development characteristics.

Data from the City of Toronto's public database was limited to developments with an application date between May 1st, 2018 and December 31st, 2019, which intended to capture all developments required to meet (a minimum) Version 3 TGS Tier 1 up to the end of 2019. Data was also limited to the 'Community Planning' category in the database search options, to exclude developments requiring only a minor variance or developments requiring a TLAB 
hearing. This decision was rationalized because TGS checklists (Version 3) only apply to developments needing a zoning-bylaw amendment, official plan amendment, or site plan application, and not to minor variances. While the goal was to capture all developments within the time frame, the City of Toronto database was not completely up-to-date such that the listed date of application did not always reflect the most recent changes to each development. For this reason, the final dataset excludes sites where the website had not been updated but is still reflective of general development trends from May 2018 to December 2019. However, there were no Version 3 Tier 2+ developments excluded from the dataset, because these sites were confirmed by correspondence with TGS staff and did not rely on manual searching of the City of Toronto database.

Data was collected from all the development applications specified above on following variables (parenthesis indicate the type of data): ward (nominal category), address (text), the date of the most recent application (date), building description (text), number of past applications (numeric), the type of each past application (nominal category: one of zoningbylaw amendment, official plan amendment, site plan application, subdivision application, condominium application), whether the site went through an OMB appeal, was withdrawn, and/or was closed in its history (binary categories), the name of the site applicant (text), the name of the site owner (text), the highest TGS tier reach (ordinal category: 1-4), the maximum number of storeys (numeric), the number of residential units where applicable (numeric), and the gross floor area of the site in square meters (numeric). GPS locations of every development were determined via Google Earth. The name of the site applicant and site owner were collected as recorded in the TGS checklist. If this information was not available in the checklist, it was collected from the applicant form, and where this was left blank, the information was collected from the planning rationale (which sometimes indicates the applicant and owner). The developer of each site was determined through an online search using a variety of development tracking websites, including UrbanToronto, BuzzBuzzToronto, ListWithUs, CondoNow, or the City of Toronto (see Sources for Data Analysis Section under References). The developer's approximate time since established, headquarters, and areas served were 
determined through the development tracking websites mentioned above or the developer's own website. In all, the purpose of this dataset was to compare characteristics of Tier 1 developments against Tier $2+$ developments (version 3) within the same general time period. Developments of type "City Agency, Corporation, \& Division" were excluded from analysis because sites developed by the City must reach at least Tier 2 by default, and so do not measure any contextual factors on the TGS Tier targeted or reached.

\section{Results}

All data analysis was conducted in Excel. In total, the dataset included 258 developments targeting Tier 1, and 36 developments targeting Tier 2+ (34 Tier 2, 1 Tier 3, and 1 Tier 4). The majority of Tier $2+$ developments occurred within the downtown core area with a few exceptions (Figure 4). Variables analyzed were sorted into three categories: site characteristics, approval characteristics, and developer characteristics. 


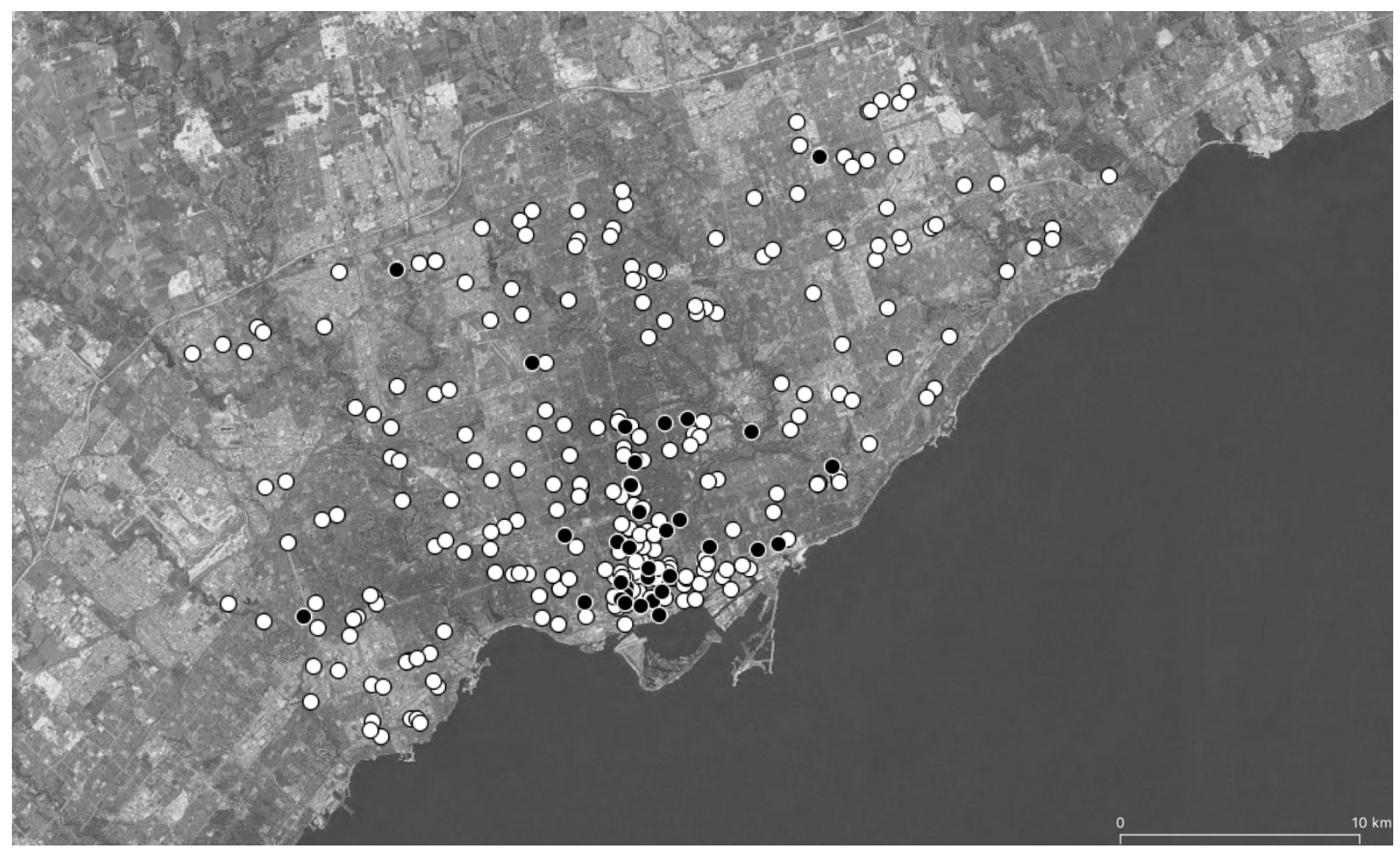

Figure 4. Location of developments by TGS Tier target in the Toronto region. Black dots indicate Tier 2+ developments and white dots indicate Tier 1 developments.

Site Characteristics

Compared to Tier 1 developments, Tier 2+ developments were more likely to be Mixed-Use or Office, but less likely to be Residential (see Figure 5). The difference in the proportion of land use types between Tier $2+$ and Tier 1 was statistically significant (Chi-Squared Test, $p$-val = $0.0003 *)$. 


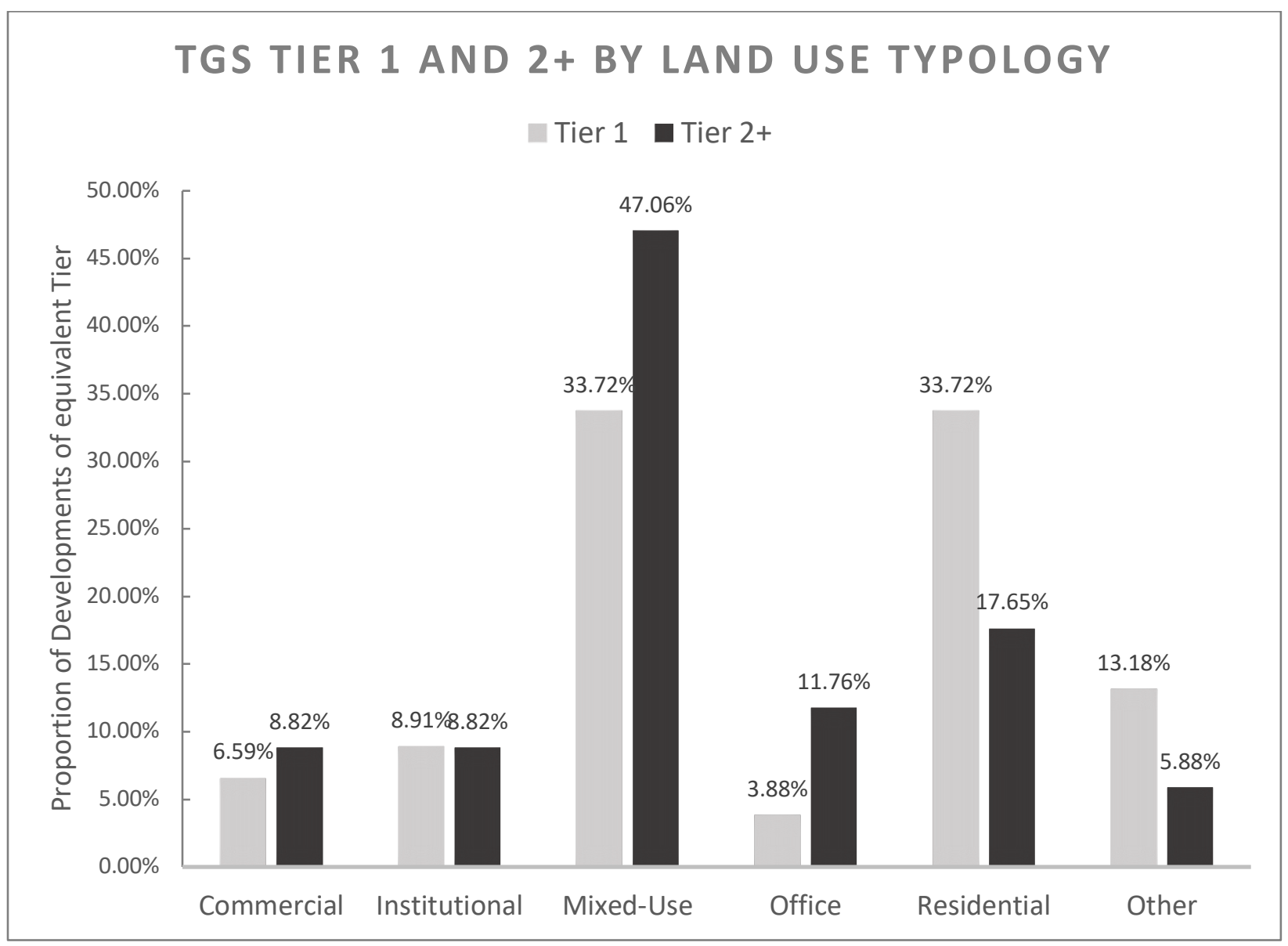

Figure 5. Land use typology breakdown by Version 3 Tier targeted for Toronto developments May 2018 to December 2019.

Tier 2+ developments were also more likely to have some component of affordable housing, as mentioned in the building description (Chi-Squared Test, $\mathrm{p}$-val $=2.744 \mathrm{E}-13^{*}$ ), however both the majority of Tier 1 and Tier 2+ developments were sold or leased at market rate. This difference is shown in Figure 6. Tier 2+ developments were less likely to include purpose-built rental units, but this difference was not statistically significant. 


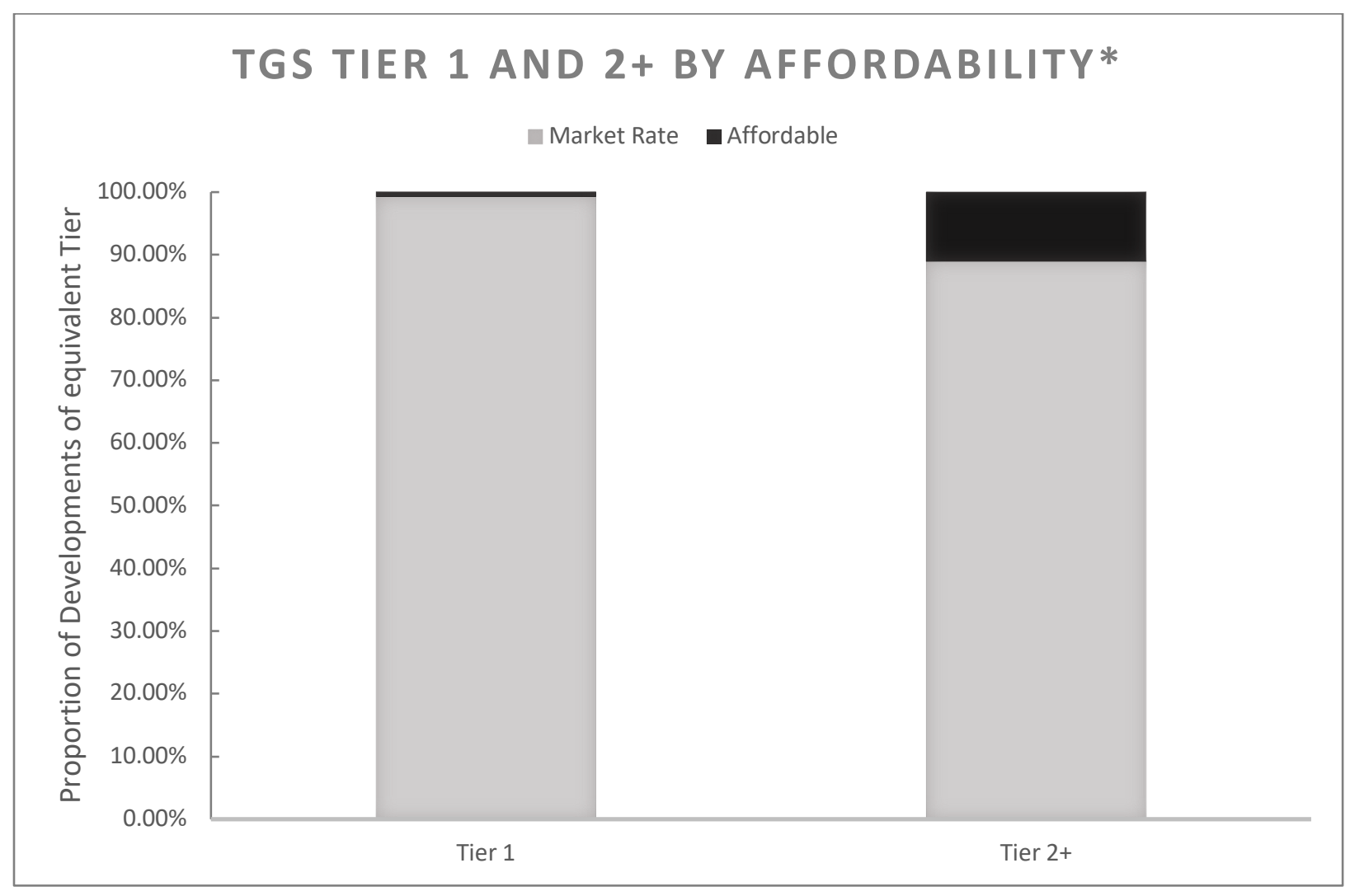

Figure 6. Proportion of affordable housing component for Toronto developments May 2018 to December 2019. (* indicates statistical significance)

Massing descriptors of the developments varied between Tier 1 and Tier $2+$ but were not all significantly different. Tier $2+$ developments tended to have more storeys (23 on average, compared to 14 on average for Tier 1) (Figure 7), residential units (where applicable, 474 on average, compared to 312 on average for Tier 1) (Figure 8), and overall GFA (49,916 on average, compared to 21,816 on average compared to Tier 1) (Figure 9). However, only the difference in storeys $\left(p-v a l=0.004^{*}\right)$ and GFA $\left(p-v a l=0.011^{*}\right)$ were statistically significant as calculated by two sample T-Tests assuming unequal variances. 


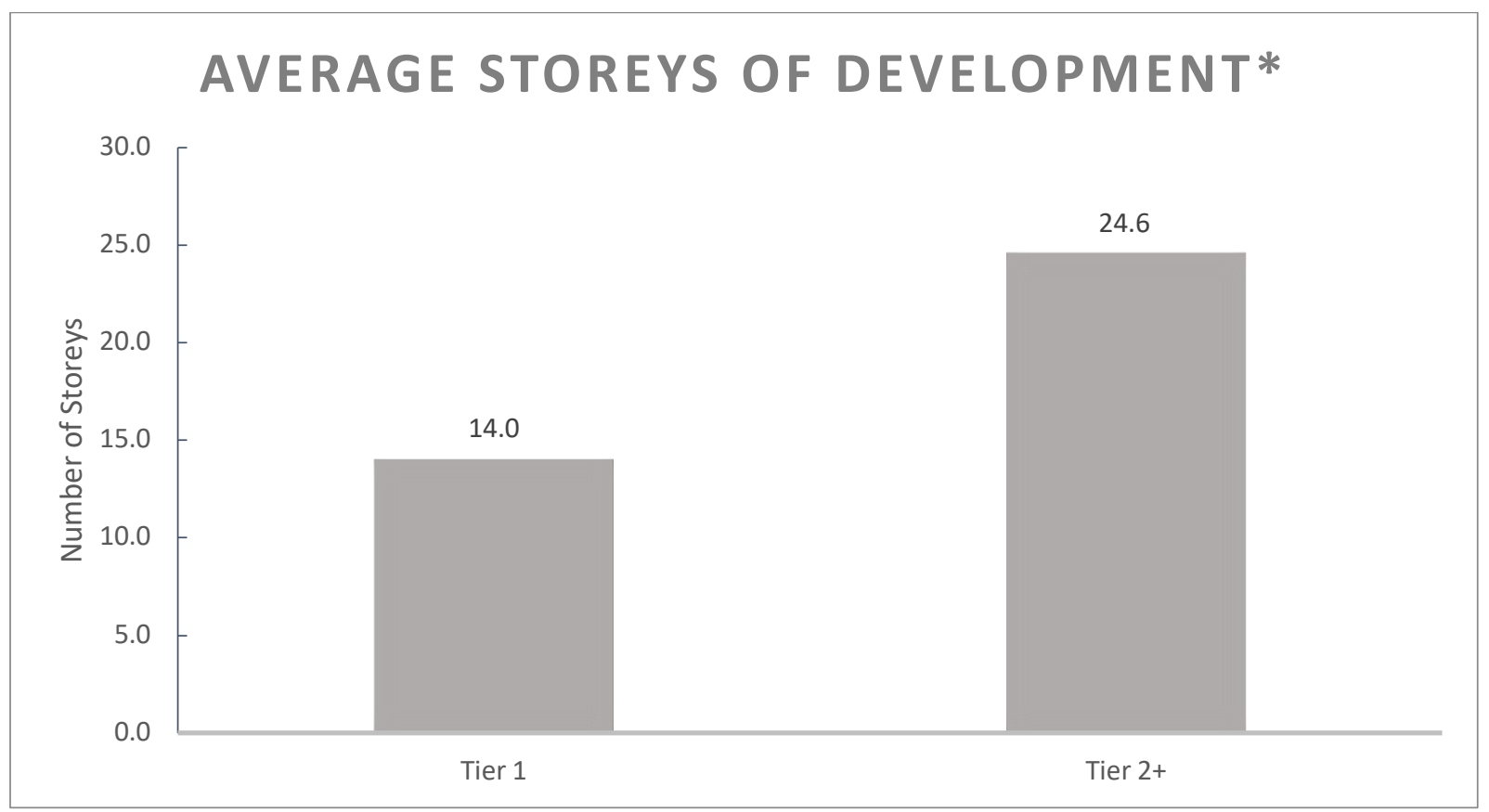

Figure 7. Average number of storeys (maximum) for Toronto developments May 2018 to December 2019.

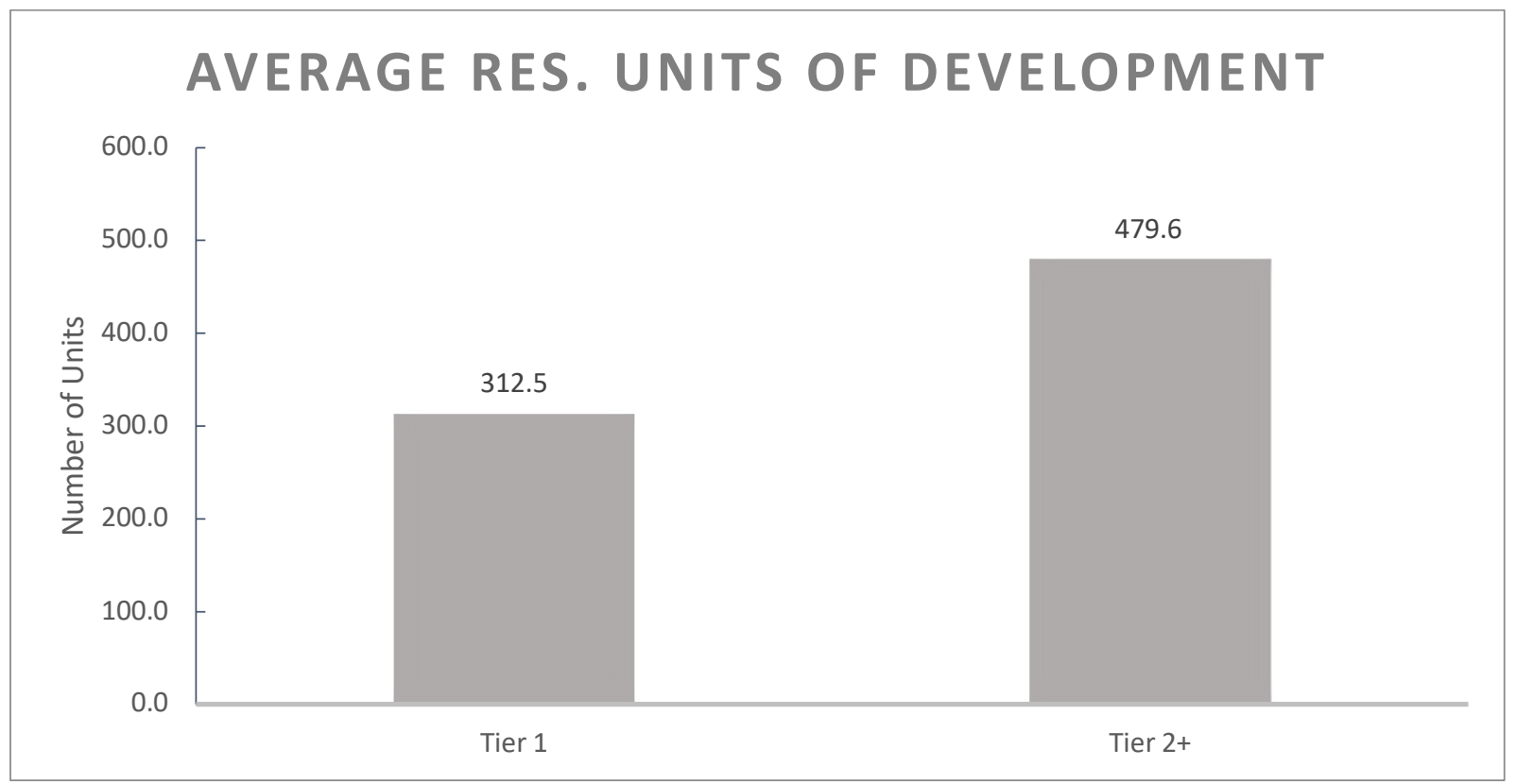

Figure 8. Average number of residential units (where applicable) for Toronto developments May 2018 to December 2019. 


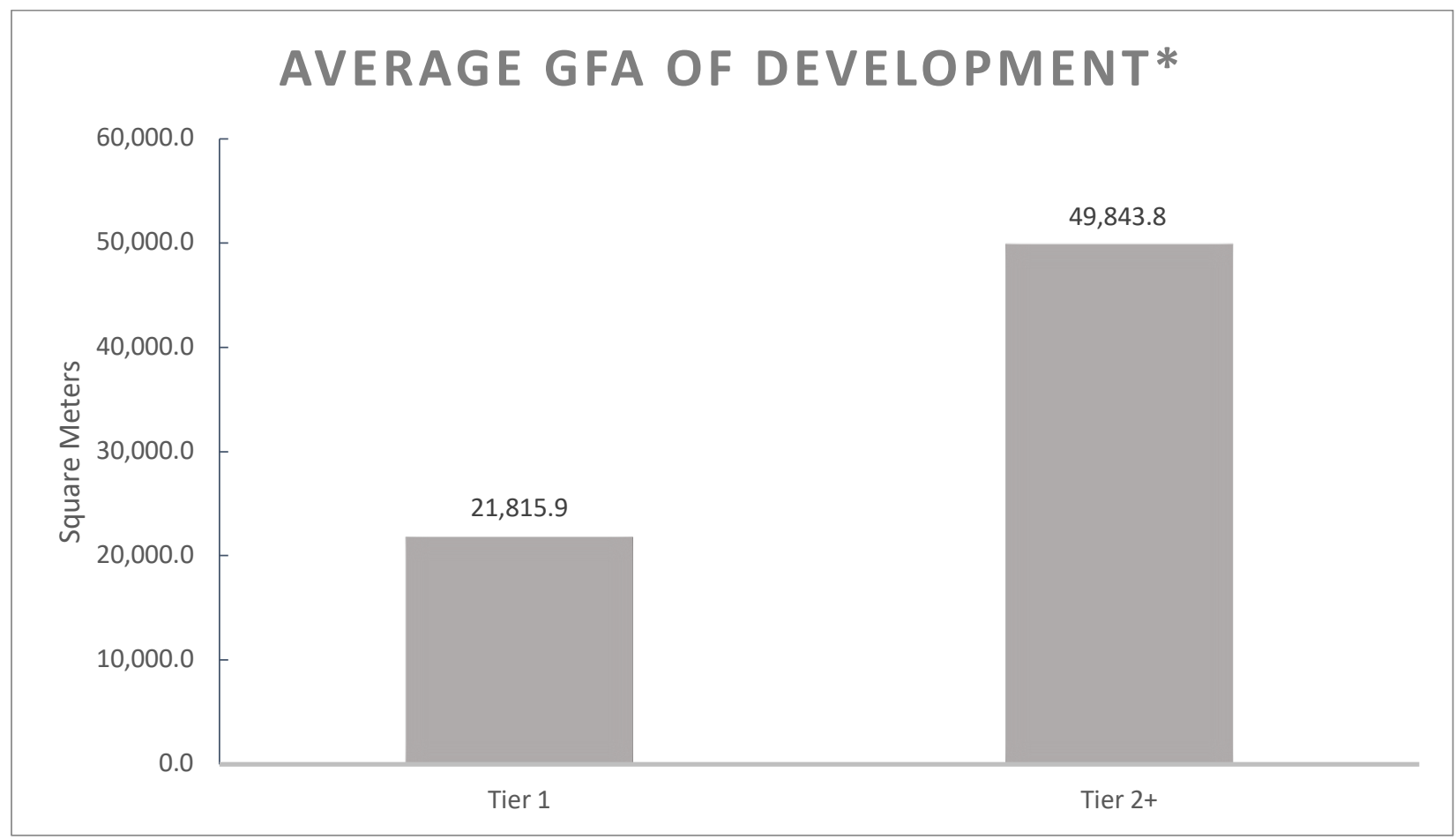

Figure 9. Average gross floor area for Toronto developments May 2018 to December 2019.

\section{Application Characteristics}

Tier 2+ developments underwent slightly more applications for the site than Tier 1 (T-Test, p-val $=0.0465^{*}$ ) and were more likely to require an OPA, ZBA, or Subdivision Approval, but not in a statistically significant way. Tier 1 developments, however, appeared to run into greater difficulties in the application process. This is evident in finding that Tier 1 developments went to appeal on 8 occasions ( 2 appeals received, 6 OMB appeals), two were closed, and one was withdrawn completely, whereas Tier 2+ developments had only one OMB appeal, no closures, and no withdrawals. 


\section{Developer Characteristics}

Since data quality about developer's characteristics was not uniform and were not available for all developments, only anecdotal observations could be made without statistical analysis. Overall, only 25 unique developers (including two unknown developers) targeted Tier 2+ and 160 unique developers targeted Tier 1 . Of these developers, 17 of 25 Tier $2+$ developers were found to have only Tier 2+ projects. In contrast, 152 of 160 Tier 1 developers were found to only Tier 1 projects. It follows that $68 \%$ of Tier $2+$ developers specialized in Tier $2+$, and the developers who conducted Tier 1 and Tier 2+ projects made up only 5\% (8) of Tier 1 developers.

In terms of experience, the average age of developers achieving Tier 1 and Tier $2+$ were revealed to be approximately the same (about 29 years for Tier 1 and 30 years for Tier $2+$ ). The youngest Tier 1 developer was under one year since established, while the youngest Tier 2+ developer was 4 years. For both Tier 1 and Tier 2+ developers, the majority were headquartered in Toronto (76\% for Tier 1 and $73 \%$ for Tier $2+$ ). Interestingly, Vancouver-based developers seemed more willing to pursue Tier $2+$, with $15 \%$ of Tier $2+$ developers being based in Vancouver, but only 1\% of Tier 1 developers being Vancouver-based. Also noteworthy was that developers based in Montreal, Cambridge, Markham, Vaughan, Etobicoke, or outside of Canada only met a maximum of Tier 1 . Figure 10 shows the breakdown of developer headquarters by region relative to Toronto. 


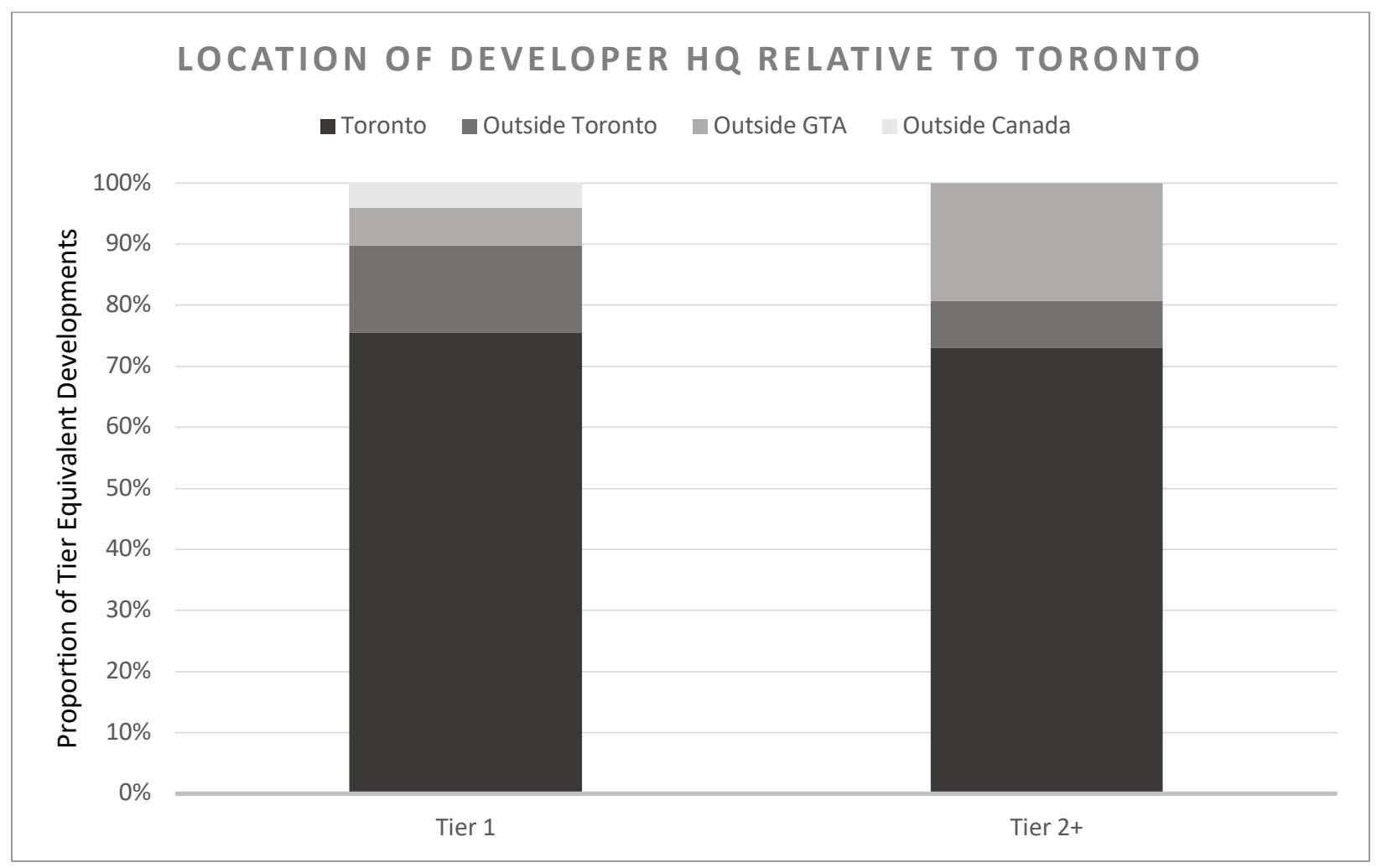

Figure 10. Location of Developer Headquarters (Head Office) for Toronto developments May 2018 to December 2019. "Outside Toronto" refers to the region outside Toronto but within the GTA. "Outside GTA" refers to the region outside the GTA but within Canada.

In comparing areas served, Tier 1 and Tier 2+ developers mostly served the GTA (59\% for Tier 1, $48 \%$ for Tier 2+). Tier 2+ developers, however, were more likely to also work in areas outside of Canada (32\%, compared to 16\% for Tier 1 developers). Whereas, Tier 1 developers were more likely to work only in Canada (84\% compared to 68\% for Tier 2+) (Figure 11). 


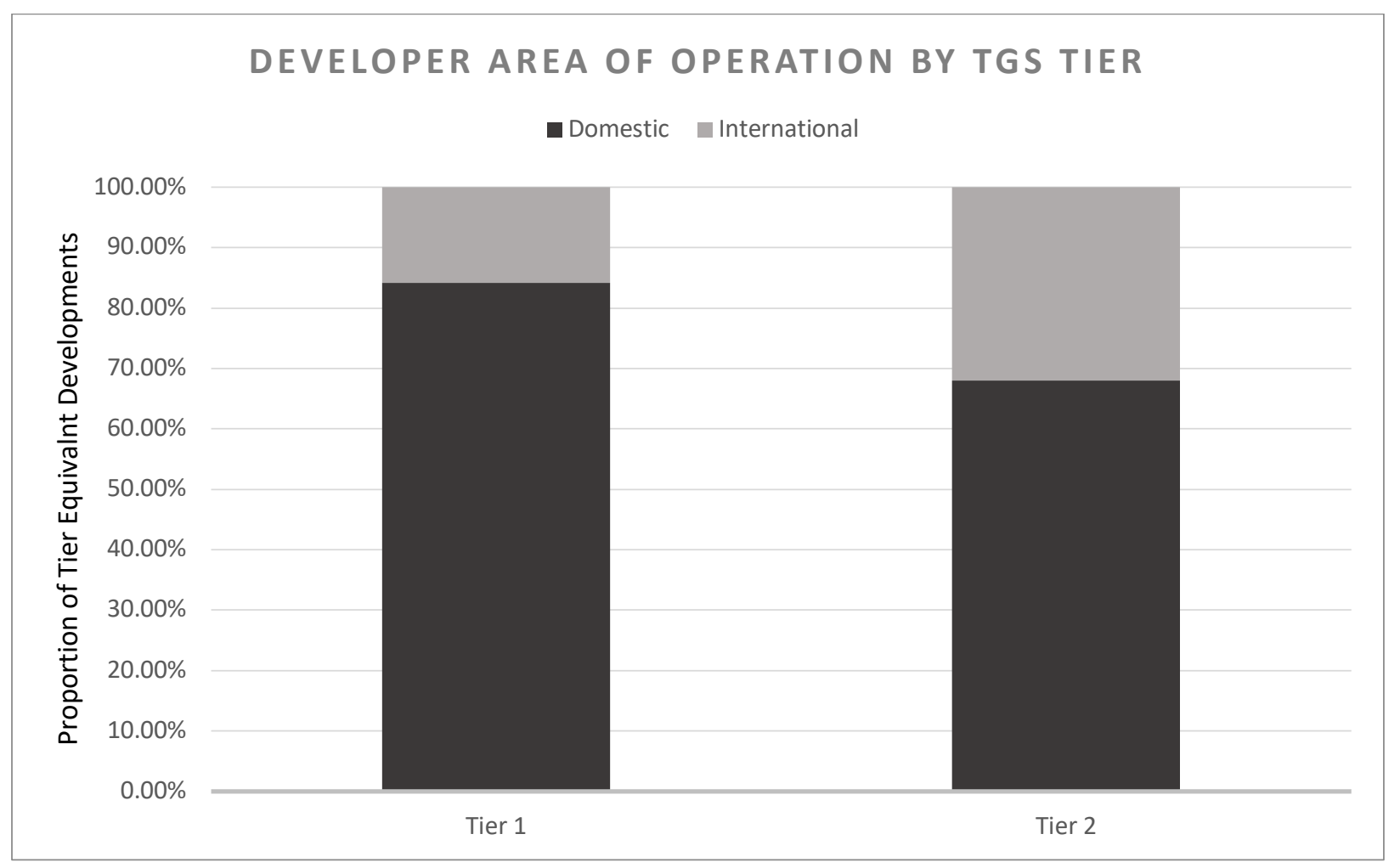

Figure 11. The area served by developers for Toronto developments May 2018 to December 2019.

\section{Part 2: Case Study Analysis}

\section{Methods}

From the dataset used for Part 1, four 'case studies' were conducted to compare in detail the differences between two developments - one targeting Tier $2+$ and one targeting Tier 1 (version 3). The development pair was selected based on similar characteristics: the two developments were ensured to be in the same ward, have the same land use type, and have the same relative scale as reflected in the GFA, number of residential units, and/or maximum number of storeys. Specifically, at least one of the following statements had to be true in order for the pair to meet the criteria: (1) the site with a smaller GFA was at least $50 \%$ the GFA of the second site, (2) the site with a smaller number of residential units was at least $50 \%$ the number 
of residential units in the second site, or (3) the site with a smaller value of max storeys was at least $50 \%$ the value of max storeys of the second site. To select each pair, a Tier 2+ development was selected randomly from all Tier 2+ developments, and then a Tier 1 development was selected randomly from the developments within the same ward that met the criteria. This was repeated four times. From this method, the following development pairs were selected: 533 King Street West \& 145 Wellington St West, 4097 Lawrence Avenue East and 80 Dale Avenue, 95 Joseph Street and 300 Bloor Street West, and 563 Gerrard Street and 10 Gamble Avenue. The first three pairs are mixed-use, and the last pair is residential. While not completely representative of the dataset, mixed-use developments were the most common type overall (36.5\%), while residential developments were the second most common (30\%). Commercial, institutional, office, and other land use types were not considered because there were no pair of developments within these categories that met all the criteria described.

A content analysis was conducted for each site regarding the planning rationales, cover letters, and the developer's website, identifying key themes in the text indicative of similarities and differences between the nature of the development and the developer. Specifically, this content analysis was used to identify the development type, developer age, developer headquarters (main office), architects involved, approvals, existing conditions, and heritage considerations. The names of the developers were not included to reduce bias of interpretation. Socioeconomic characteristics were determined using Statistics Canada Census Tract data in combination with the GIS tool Census Mapper (2016). Transit access and accessibility to downtown (defined as the boundary of Old Toronto) was determined via Google Maps.

Results

Case Study 1: 533 King Street West \& 145 Wellington St West

533 King Street West and 145 Wellington St West are two proposed mixed-use residentialcommercial developments in the Spadina-Fort York ward of Toronto with approximately similar 
GFAs (54,709 and 50,562 SM). 533 King Street West is recognized for targeting Tier 2 while 145 Wellington St West targeting Tier 1 only (Table 4).

\begin{tabular}{|c|c|c|}
\hline Criteria & 533 King St. & 145 Wellington St. W \\
\hline Target TGS Tier & Tier $2^{*}$ & Tier 1 \\
\hline Ward & Spadina-Fort York & Spadina-Fort York \\
\hline Development Type & $\begin{array}{l}\text { Mixed-Use Residential } \\
\text { Commercial }\end{array}$ & $\begin{array}{l}\text { Mixed-Use Residential } \\
\text { Commercial }\end{array}$ \\
\hline GFA & $54,709 \mathrm{SM}$ & $50,562 \mathrm{SM}$ \\
\hline Number of Units (Res.) & 476 & 440 \\
\hline Storeys (Maximum) & 16 & 65 \\
\hline Developer Type & Luxury Condo Developer & Investment Trust \\
\hline Developer Age & 25 years & 24 years \\
\hline Developer Headquarters & Vancouver, Canada & Toronto, Canada \\
\hline Architect(s) & $\begin{array}{l}\text { BIG (Denmark), Diamond } \\
\text { Schmitt Architects (Toronto), } \\
\text { Sweeny \& Co. Architects Inc } \\
\text { (Toronto) }\end{array}$ & $\begin{array}{l}\text { Turner Fleischer Architects } \\
\text { (Toronto) }\end{array}$ \\
\hline Approval(s) & $\begin{array}{l}\text { ZBA (2016, with OMB } \\
\text { Appeal), SPA (2018) }\end{array}$ & ZBA (2019) \\
\hline Existing Conditions & Seven buildings (mixed-use) & $\begin{array}{l}\text { One under-utilized office } \\
\text { building }\end{array}$ \\
\hline Heritage & $\begin{array}{l}\text { Two heritage buildings to be } \\
\text { partially conserved }\end{array}$ & NA \\
\hline Transit Access & $\begin{array}{l}\text { 1-minute walk to nearest } \\
\text { streetcar stop. 21-minute } \\
\text { walk to Union Station. }\end{array}$ & $\begin{array}{l}\text { 2-minute walk to nearest } \\
\text { streetcar stop. 6-minute } \\
\text { walk to Union Station. }\end{array}$ \\
\hline $\begin{array}{l}\text { Accessibility to Downtown } \\
\text { (Old Toronto) Boundary }\end{array}$ & NA (Within the Downtown) & NA (Within the Downtown) \\
\hline
\end{tabular}




\begin{tabular}{|l|l|l|}
\hline $\begin{array}{l}\text { Average Household Income of } \\
\text { Dissemination Area (2015) }\end{array}$ & $\$ 119,000$ & $\$ 256,000$ \\
\hline
\end{tabular}

Table 4. Development characteristic comparisons for 533 King Street and 145 Wellington Street. Grey cells indicate criteria that was approximately similar between the two sites (same ward and development type, as well as approximately similar GFA, number of residential units, and/or maximum storeys). *As of January 2020, the status of 533 King Street as Tier 2 is under review due to the development not meeting newly imposed TGS absolute energy targets.

Several differences between the two sites are worth noting. The first is the massing: 145 Wellington is a high-rise tower with limited space whereas 533 King is a lower-density building with units spread across a much greater plot of land. Since many developments in the downtown area of Toronto have extremely limited lot sizes, this emphasizes the scale and significance of 533 King compared to 145 Wellington, despite have similar GFA.

The second consideration is the overall intent of the project. 145 Wellington appears to be addressing a need for housing, specifically rental-units in the heart of the unaffordable downtown. This is particularly important since purpose-built rentals have mostly diminished since the 1990s being replaced by condo units rented out by the owner (Rosen \& Walks, 2014). Consequently, the rental market has become more expensive, pricing out middle-income earners (Madani et al., 2019). 533 King on the other hand has residential units priced at an average of $\$ 2,052$ per square foot ("King Toronto Condos", 2019), about eight times the GTA average for condominiums of a similar height (Altus Group, 2019) indicating that this development is directed towards the wealthiest cohort of consumers. Moreover, renderings depict obvious biophilic design elements, in which units are attached to miniature greenhouses and every roof is covered with vegetation to have the appearance of a forested mountain top (Vincent, 2018). All of this indicates an apparent association between the demand for green components, particularly biophilic design components, and the price of units. 
Case Study 2: 80 Dale Avenue and 4097 Lawrence Avenue East

80 Dale Avenue and 4097 Lawrence Avenue East are two residential developments in the Scarborough-Guildwood ward of Toronto. Both developments are proposed to be 12 storeys, with 80 Dale Avenue having a GFA of 22,612 SM and 4097 Lawrence having a GFA of 16,287 SM. 80 Dale is recognized for targeting Tier 2 while 4097 Lawrence is only targeting Tier 1.

\begin{tabular}{|c|c|c|}
\hline Criteria & 80 Dale Avenue & 4097 Lawrence Ave. E. \\
\hline Target Tier & Tier 2 & Tier 1 \\
\hline Ward & Scarbourough-Guildwood & Scarbourough-Guildwood \\
\hline Development Type & Residential & Residential \\
\hline GFA & $22,612 \mathrm{SM}$ & $16,287 \mathrm{SM}$ \\
\hline Number of Units (Res.) & 285 & 216 \\
\hline Storeys (Maximum) & 12 & 12 \\
\hline Developer Type & General Developer & Condo Developer \\
\hline Developer Age & 16 years & 1 year \\
\hline Developer Headquarters & Toronto, Canada & Toronto, Canada \\
\hline Architect(s) & Standard Practice (Toronto) & $\begin{array}{l}\text { Turner Fleischer Architects } \\
\text { (Toronto) }\end{array}$ \\
\hline Approval(s) & $\begin{array}{l}\text { SPA (2018), ZBA (2019), OPA } \\
\text { (2019) }\end{array}$ & ZBA (2019), SPA (2019) \\
\hline Existing Conditions & $\begin{array}{l}\text { Vacant site adjacent to a Golf } \\
\text { Course }\end{array}$ & One small bungalow \\
\hline Heritage & NA & NA \\
\hline Transit Access & $\begin{array}{l}\text { 2-minute walk to nearest bus } \\
\text { stop. } 15 \text {-minute walk to } \\
\text { nearest GO station. }{ }^{*}\end{array}$ & $\begin{array}{l}\text { 1-minute walk to nearest } \\
\text { bus stop. 18-minute walk to } \\
\text { nearest GO station. }\end{array}$ \\
\hline $\begin{array}{l}\text { Accessibility to Downtown } \\
\text { (Old Toronto) Boundary }\end{array}$ & 44-minutes via transit. & 51-minutes via transit. \\
\hline
\end{tabular}




\begin{tabular}{|l|l|l|}
\hline $\begin{array}{l}\text { Average Household Income of } \\
\text { Dissemination Area (2015) }\end{array}$ & $\$ 92,000$ & $\$ 75,000$ \\
\hline
\end{tabular}

Table 5. Development characteristic comparisons for 80 Dale Avenue and 4097 Lawrence Avenue East. *The site is also proposed to create a new, accessible landscaped path connecting to the nearby GO Station, that would reduce this time.

The discrepancies between 80 Dale Avenue and 4097 Lawrence Avenue are not obvious, but several factors are worth considering. First, the developer for 80 Dale is more well established than the developer for 4097 Lawrence (in terms of years of experience), which indicates again that Tier $2+$ achievement may require a certain threshold of experience. This is consistent with the overall findings showing that the youngest developer for Tier $2+$ was 4 years since established while the youngest Tier 1 developer was less than a year old. 80 Dale also appears to be in area that could expect a higher potential unit price, due to a proposed path that will connect the site directly to the GO station and the higher average household income (as a proxy indicating slightly higher consumer demand of housing in that area).

\section{Case Study 3: 300 Bloor Street West and 95 St Joseph Street}

300 Bloor Street West and 95 St Joseph Street are two high density mixed-use developments in the University-Rosedale ward with 39 storeys and 29 storeys respectively. 95 Joseph street is significantly larger in scale, but the developments are similar for being well above 18 floors in height, which was the average for all developments. Both developments also have underwent some form of heritage protection of existing assets. 300 Bloor Street West is recognized for achieving Tier 2 while 95 St Joseph only achieved Tier 1.

\begin{tabular}{|l|l|l|}
\hline Criteria & 300 Bloor St. W. & 95 St Joseph St. \\
\hline Target Tier & Tier 2 & Tier 1 \\
\hline Ward & University-Rosedale & University-Rosedale \\
\hline
\end{tabular}




\begin{tabular}{|c|c|c|}
\hline Development Type & $\begin{array}{l}\text { Mixed-Use Residential, } \\
\text { Commercial, Institutional }\end{array}$ & $\begin{array}{l}\text { Mixed-Use Residential, } \\
\text { Commercial, Institutional }\end{array}$ \\
\hline GFA & 26,297 SM & $49,210 \mathrm{SM}$ \\
\hline Number of Units (Res.) & 249 & 502 \\
\hline Storeys (Maximum) & 29 & 39 \\
\hline Developer Type & General Developers (2) & General Developer \\
\hline Developer Age & 6 and 3 years (at minimum) & 35 \\
\hline Developer Headquarters & $\begin{array}{l}\text { Toronto, Canada and } \\
\text { Mississauga, Canada }\end{array}$ & Toronto, Canada \\
\hline Architect(s) & KPMB (Toronto) & Brook Mcllroy (Toronto) \\
\hline Approval(s) & ZBA (2017, revised in 2019) & ZBA (2019), SPA (2019) \\
\hline Existing Conditions & $\begin{array}{l}\text { A parking lot and two } \\
\text { buildings (One church, and a } \\
\text { small corporate office } \\
\text { building) }\end{array}$ & $\begin{array}{l}\text { One building (religious } \\
\text { centre, including a chapel } \\
\text { attached) }\end{array}$ \\
\hline Heritage & $\begin{array}{l}\text { Two buildings recognized as } \\
\text { heritage assets that are to be } \\
\text { partially conserved }\end{array}$ & $\begin{array}{l}\text { The façade of the non- } \\
\text { heritage designated chapel } \\
\text { to be retained intact }\end{array}$ \\
\hline Transit Access & $\begin{array}{l}\text { 1-minute walk to nearest } \\
\text { bikeshare station. 2-minute } \\
\text { walk to nearest bus stop. 3- } \\
\text { minute walk to nearest } \\
\text { subway station. }\end{array}$ & $\begin{array}{l}\text { 1-minute walk to nearest } \\
\text { bus stop. 6-minute walk to } \\
\text { nearest subway station. }\end{array}$ \\
\hline $\begin{array}{l}\text { Adjacency to Downtown (Old } \\
\text { Toronto) Boundary }\end{array}$ & NA (Within the Downtown) & NA (Within the Downtown) \\
\hline $\begin{array}{l}\text { Average Household Income of } \\
\text { Dissemination Area (2015) }\end{array}$ & $\$ 114,000$ & $\$ 68,000$ \\
\hline
\end{tabular}


Table 6 (Previous Page). Development characteristic comparisons for 300 Bloor Street West and 95 St Joseph Street.

Unlike the other pairs of developments, 300 Bloor St. W and 95 St Joseph St. seem to have a more or less similar motivations for development and exist within similar contexts. Both are proposed mixed-use with condominium residential units (ownership only), retail space, institutional space, and are planning to preserve existing heritage assets. The most obvious differences between the developments is that 300 Bloor is being developed by two relatively younger firms with no more than 6 years each, whereas 95 St Joseph is being developed by a 35-year old firm. This makes the pair different from the previous case study, since the Tier 2 developers have less experience. Both firms also appear to have sustainable development as a normative goal, showing precedents on their website, however one of the 300 Bloor developers is notable for being nominated as the Building Industry and Land Development Association (BILD) green builder of the year, and won an award for green marketing in 2018. More importantly, of the three developments completed by one of the Tier 2 developers since May 2018, all three met Tier 2 (Version 3). In comparison, the 95 St Joseph developer met Tier 2 several times in the past under Version 2, but none under Version 3. This may indicate that the requirements added under Version 3 made it less realistic for certain developers to meet Tier 2, but not for other developers. It may also indicate that consistent commitment to Tier $2+$ in the past is a good predictor for future commitment to TGS sustainable development goals.

\section{Case Study 4: 563 Gerrard Street and 10 Gamble Avenue}

563 Gerrard Street and 10 Gamble Avenue are two 3-storey mixed-use developments in the Toronto Danforth ward. Both developments are categorized as 'low-rise residential' according to the TGS checklist. 563 Gerrard is proposed to have 13 residential units and 10 Gamble Avenue is proposed have 5 residential units. Both sites have developers not recognized officially online, indicating they are likely projects being proposed by individuals or small business with no online presence. 563 Gerrard is recognized for targeting Tier 2 while 10 Gamble only targeted Tier 1. 


\begin{tabular}{|c|c|c|}
\hline Criteria & 563 Gerrard Street & 10 Gamble Avenue \\
\hline Target Tier & Tier 2 & Tier 1 \\
\hline Ward & Toronto-Danforth & Toronto-Danforth \\
\hline Development Type & Low-Rise Residential & Low-Rise Residential \\
\hline GFA & $2,533 \mathrm{SM}$ & 316 SM \\
\hline Number of Units (Res.) & 13 & 5 \\
\hline Storeys (Maximum) & 3 & 3 \\
\hline Developer Type & Unknown & Unknown \\
\hline Developer Age & Unknown & Unknown \\
\hline Developer Headquarters & Unknown & Unknown \\
\hline Architect(s) & Avtech Designs (Pickering) & $\begin{array}{l}\text { Trevor Gain \& Associates } \\
\text { (Markham) }\end{array}$ \\
\hline Approval(s) & SPA (2018) & SPA (2019) \\
\hline Existing Conditions & Vacant & Vacant \\
\hline Heritage & NA & NA \\
\hline Transit Access & $\begin{array}{l}\text { 2-minute walk to nearest } \\
\text { streetcar stop. 3-minute walk } \\
\text { to nearest subway station. }\end{array}$ & $\begin{array}{l}\text { 1-minute walk to nearest } \\
\text { Bike Share station. 1-miunte } \\
\text { walk to nearest bus station. } \\
\text { 20-minute walk to nearest } \\
\text { subway station. }\end{array}$ \\
\hline $\begin{array}{l}\text { Adjacency to Downtown (Old } \\
\text { Toronto) Boundary }\end{array}$ & 3-minute walk. & $\begin{array}{l}25 \text {-minute walk. } 13 \text {-minutes } \\
\text { via public transit. }\end{array}$ \\
\hline $\begin{array}{l}\text { Average Household Income of } \\
\text { Dissemination Area (2015) }\end{array}$ & $\$ 89,000$ & $\$ 55,000$ \\
\hline
\end{tabular}

Table 7. Development characteristic comparisons for 563 Gerrard Street and 10 Gamble Avenue. 
While both developments are small in ambition compared to the previous case studies, there are several key differences. The first is location. 563 Gerrard exists in a busy area of the Danforth that is very close to the downtown core, with potentially higher demand for units. 10 Gamble is further north from Danforth and further from the downtown core, indicating potentially less demand for units. As with 533 King Street, the higher demand for units may attract competitive consumers willing to pay a premium if the housing include sustainable or biophilic components.

The second difference is relative size. 563 Gerrard has a GFA about 8 times the size of 10 Gamble, despite both being 3 storeys and having 10 or less residential units. This is important because general development characteristic analysis suggests that Tier $2+$ developments tend to be larger in general, having about 2.3 times larger GFAs on average, and a minimum of 205 SM GFA (compared to 76.5 SM GFA). This might indicative that Tier 2+ standards are only financially feasible beyond a certain threshold of scale, and that in general, it is easier for a developer to include sustainable components in larger developments. This may be a result of economies of scale (it is more financially feasible to include sustainable components when implemented at a larger scale), or due smaller developments being developed by individuals or small developers with less capital and experience to include sustainable components.

\section{Discussion}

Despite contextual variation in sites, there are several relevant conclusions that emerge in comparing Tier 1 developments to Tier 2+ developments from May 2018 to December 2019. First, the DC refund does not appear to be a worthwhile financial incentive on its own, as $88 \%$ of developments did not go beyond Tier 1 . Of the $12 \%$ of developments that targeted or met Tier 2+, they were typically larger, higher-density, mixed-use, and underwent a slightly longer and more complex application process. This is supported by the observations that on average, Tier 2+ developments were $76 \%$ taller with $53 \%$ more residential units and GFAs $128 \%$ of Tier 1 . Tier $2+$ developments were also about $40 \%$ more likely to be mixed-use. These types of 
development are likely to get the most attention from City staff as they are expected to provide the greatest range of services, jobs, and residential units. However, without a clear incentive strategy, these developments are likely motivated by a number of external factors that can be reasonably speculated given the evidence from the case study analyses.

One clear motivation is market demand. This includes the developments geared towards luxury consumers, such as 533 King Street, where sustainable components are seen as an additional product, particularly components involving biophilic design, and result in a cost premium for units. In other words, these developments result from consumer demand for sustainable or biophilic components. This would include all obvious biophilic components, which are directly visible or experienced (such as rooftop gardens), as well as non-biophilic sustainable components with a potential for costs savings (mainly energy efficient technology).

Another motivation is likely reward via alignment with urban policy, meaning that a development would demonstrate its commitment to government policy in exchange for a financial reward. Formally, this is achieved via existing TGS requirements. In particular, developments led by government agencies, such as TCHC and Housing Now are required to meet Tier 2 standards (even if the development is not under the 'City-Owned' category), which explains why Tier 2+ was associated with affordable housing. Informally, developments that cater to Toronto's municipal political agenda may encourage the City to look favourably towards such development proposals. In the case of the TGS, the achievement of Tier 2+ may act as an informal quid pro quo mechanism, which reduces a development's risk of undergoing a longer, more financially burdensome application process. This is supported by the evidence showing that Tier 2+ developments faced no withdrawals or closed applications, and only one OMB appeal (for 533 King Street, being a particularly unique case given its scale and unorthodox design). Thus, the assumption is that developers may "give legs" to their development by meeting Tier $2+$ requirements through the TGS and by allocating affordable housing units, which the City recognizes as desired policy directions in the Official Plan (City of Toronto, 2019c). In addition to such informal structural incentives, developers may look to 
grants that require sustainable building elements to be eligible. Particularly for small-scale developments, the City provides grants for energy-efficient technology, tree planting, green roofs, pollinator gardens, and waste reduction (City of Toronto, 2020c). Externally, there are other incentives, such as through green certifications such as LEED and ENERGY STAR (CaGBC, 2020), which can be paired with TGS as many of the requirements overlap (City of Toronto, 2019). Some TGS metrics may also be met as a requirement for other grants, for example, the Rental Construction Financing program offered by the federal government is aimed to promote rental housing but requires a 15\% decrease in energy intensity and GHG emissions (compared to a conventional average from 2015) (CMHC, 2018a). A similar requirement for energy efficiency is needed for the National Housing Co-investment Fund, which aims to support mixed-use, mixed-income housing (CMHC, 2018b). These funding models couple two different policy aims, which gives the developer an opportunity to find multiple financial benefits from the same sustainable components (for example, if energy-saving technology is a requirement for the DC refund via TGS Tier 2 and an affordable housing grant).

To summarize, some Tier $2+$ developments appear to be a result of consumer demand, while others may be incentivized through favourable approval prospects and/or through financial incentives that can combine with the DC refund to make the overall investment worthwhile. These two motivations are not mutually exclusive. For luxury developments, sustainable design may help align the development with policy goals (reducing the risk of opposition by the municipality) and can be financially supported through grants. However, developments with a significant focus on consumer demand may limit the use of other incentives. 533 King Street, for example, has an unconventional design for the purpose of providing a highly biophilic experience for residents, but the development was taken to the OMB in 2016, the unorthodox design was critiqued extensively by City Council in 2018, and its Tier 2 status is currently under review (City of Toronto, 2018e). On the other hand, developments focused on favourable application processing or grants may be limited in terms of design (and therefore consumer demand) in an attempt to meet a long list of requirements. 
The analysis also indicates something about the types of developers that are usually able to meet Tier 2+ standards ('Tier 2+ Developers'). First, Tier 2+ developers appear to have a certain threshold of experience, since there were no Tier 2+ developers younger than 4 years, but a number of Tier 1 developers that were less than one year old. This may be a result of new developers having limited capital to invest in sustainable projects. Second, Tier $2+$ developers often established themselves as having the capacity to meet Tier 2, as in the case with 300 Bloor St. West. This is evident in the fact that the majority (68\%) of Tier $2+$ developers had only Tier $2+$ projects ongoing while 95\% of Tier 1 developers had only Tier 1 projects ongoing (between May 2018 and December 2019), suggesting Tier 2+ may require a certain level of niche specialization. Specifically, developers may choose to incorporate sustainable technology into their practice, which may allow them to develop efficient protocols and strategies for meeting voluntary TGS standards. This would also help establish informal but meaningful relationships with the municipality. Not all developers can be expected to conduct themselves in such way, but it points to a shift in culture within the development industry. Ultimately these observations suggest that meeting TGS Tier 2+ standards will depend upon a developer's investment capacity, risk aversion, their relationship with the City, and their development experience.

\section{Conclusion and Recommendations}

The TGS is a hugely significant regulatory tool for modifying the behaviour of developers in Toronto. Its impact has led to a considerable shift towards sustainable development practices, resulting in positive benefits in terms of climate change mitigation and ecological sustainability. While sustainable development is challenged by the status quo of conventional development, this paper points to several opportunities for formal and informal incentivization strategies. Informally, consumer demand for sustainable or biophilic design can be capitalized upon for certain developments geared towards consumers with the financial means. In other cases, government grants that tie together multiple policy agendas can incentivize the fulfillment of sustainable development in addition to other policy goals, such as housing affordability. As it 
now exists, the DC refund does not appear to be a widely successful financial incentive, but this could be modified through increasing the refund cap rates or through implementing new standardized incentives. Formalized expedited processing in particular could help encourage sustainable development without requiring additional funding or grants. Importantly, such incentives should be predictable and transparent, so that developers can reduce risk and therefore development costs, which may be offloaded onto consumers. One challenge pertaining to this is the lack of clarity regarding the City's negotiations with developers regarding sustainable development, which may increase risk. However, if the TGS phased tier approach is accepted (in which all tiers will eventually become mandatory), this would improve both the clarity of what's expected from developers and gradually modify the norm towards sustainable ideals.

Ultimately, the TGS is a promising tool that strives to maintain resilience in both local and global ecosystems. While it is successful for certain projects (mostly large-scale and mixed-used), there is still opportunity to encourage higher tier sustainable development in the wider development sector through stronger incentive and regulatory mechanisms. Learning from the challenges and opportunities of the TGS will help to improve the implementation of green standards for the sake of improving urban resilience, meaning the maintenance of alternative stable states that can sustain human communities through ecological processes. In this way, the TGS and other green standards will help in the effort to prevent global ecological catastrophe.

\section{Future Research Directions and Considerations}

This report has a limited scope as its findings are restricted to observations of development from May 2018 to December 2019. Consequently, future research will be required to assess the functionality and success of the TGS in both regulating and encouraging sustainable development in Toronto. This would require continuous monitoring and evaluation of development characteristics, comparing those able to meet voluntary tiers with those able to meet only the minimum requirements. Additionally, as amendments are made to the TGS 
(through the ZEBF phased approach or otherwise), assessing the effect of these amendments would require analysis on the changes to development characteristics overtime. Future research could also involve interviews with developers, which could better assess the challenges and barriers to achieving voluntary tiers of the TGS as the developer conceives it. In particular, information on the quid quo pro mechanism of reaching TGS Tier $2+$ in exchange for favourable optics towards the development approval body is purely speculative in this report but could be substantiated on evidence through formal interviews with developers and City staff. Another area of interest future research could investigate is the existence of trade-offs between consumer demand as one incentive and strict grants (in terms of requirements) as another incentive. Finally, comparative analysis with other similar green building programs may help further reveal the strengths and weaknesses of the TGS as a regulatory tool.

\section{References}

Ahmadi, F., \& Toghyani, S. (2011). The Role of Urban Planning in Achieving Sustainable Urban Development (SSRN Scholarly Paper ID 1980454). Social Science Research Network. https://papers.ssrn.com/abstract=1980454

Altus Group. (2019). 2019 Canadian Cost Guide. Retrieved from: https://www.altusgroup.com/services/reports/canadian-cost-guide-2019/

Barrett, N. (Photographer). (2017). More than 2,400 birds killed in collisions with buildings were recovered in the GTA last year. [photograph]. Toronto. Retrieved from: https://www.easybib.com/guides/citationguides/apa-format/how-to-cite-a-photo-digital-image-apa/

Barry, J. (2020). A Genealogy of Economic Growth as Ideology and Cold War Core State Imperative. New Political Economy, 25(1), 18-29. https://doi.org/10.1080/13563467.2018.1526268

Ben-Eli, M. U. (2018). Sustainability: Definition and five core principles, a systems perspective. Sustainability Science, 13(5), 1337-1343. https://doi.org/10.1007/s11625-018-0564-3 
Boudreau, J.-A., Hamel, P., Jouve, B., \& Keil, R. (2006). Comparing metropolitan governance: The cases of Montreal and Toronto. Progress in Planning, 66(1), 7-59. https://doi.org/10.1016/j.progress.2006.07.005

Brown, J. (2009). Democracy, sustainability and dialogic accounting technologies: Taking pluralism seriously. Critical Perspectives on Accounting, 20(3), 313-342. https://doi.org/10.1016/j.cpa.2008.08.002

[CaGBC] Canada Green Building Council. (2020). Incentives. Retrieved from: https://www.cagbc.org/CAGBC/Programs/LEED/Incentives.aspx

Chaplin, G., \& Wyton, P. (2014). Student engagement with sustainability: Understanding the value-action gap. International Journal of Sustainability in Higher Education, 15(4), 404-417. https://doi.org/10.1108/IJSHE$\underline{04-2012-0029}$

City of Toronto. (2016). Implementation Guidelines for Section 37 of the Planning Act. Retrieved from: https://www.toronto.ca/wp-content/uploads/2017/08/8f45-Implementation-Guidelines-for-Section-37of-the-Planning-Act-and-Protocol-for-Negotiating-Section-37-Community-Benefits.pdf

City of Toronto. (2017). Toronto Green Standard Review and Update. Retrieved from: https://www.toronto.ca/legdocs/mmis/2017/pg/bgrd/backgroundfile-107359.pdf

City of Toronto. (2018a). Energy Strategy Terms of Reference. Retrieved from: https://www.toronto.ca/wpcontent/uploads/2018/01/9446-CEP-Energy-Strategy-Terms-of-Reference-Jan-2018.pdf

City of Toronto. (2018b). Toronto Green Standard V3: Sustainability Requirements for New Development in Toronto. Retrieved from: https://www.toronto.ca/wp-content/uploads/2018/03/8f44-City-Planning-TGSV3-4-storey-res-and-all-non-res.pdf

City of Toronto. (2018c). Toronto Green Standard Version 3 - Review of Potential Incentives and Results of Additional Consultation. Retrieved from: https://www.toronto.ca/legdocs/mmis/2018/pg/bgrd/backgroundfile-115478.pdf

City of Toronto. (2018d). Bird-Friendly Development Guidelines: Best Practices: Glass. Retrieved from https://www.toronto.ca/wp-content/uploads/2017/08/8d1c-Bird-Friendly-Best-Practices-Glass.pdf 
City of Toronto. (2018e). 489-539 King Street West - Zoning Amendment Application - Request for Direction Report. Retrieved from: https://www.toronto.ca/legdocs/mmis/2018/te/bgrd/backgroundfile-118265.pdf

City of Toronto. (2019). Toronto LEED Supplement: Summary Comparison. Retrieved from: https://www.toronto.ca/wp-content/uploads/2019/03/8e83-city-planning-Toronto-Green-Standard-v3$\underline{\text { LEED-Supplement.pdf }}$

City of Toronto. (2019b). TORONTO GREEN STANDARD PROGRAM - TIER 2, 3 and 4 CAP. Retrieved from: https://www.toronto.ca/wp-content/uploads/2019/10/966b-Tier-2-Rates-Nov-1-2019.pdf

City of Toronto. (2019c). Toronto Official Plan Office Consolidation (Chapters 1-5 \& Schedules 1-4). Retrieved from: https://www.toronto.ca/wp-content/uploads/2019/06/8f06-OfficialPlanAODA_Compiled-3.0.pdf

City of Toronto. (2020a). Toronto Green Standard Version 3. Retrieved from: https://www.toronto.ca/citygovernment/planning-development/official-plan-guidelines/toronto-green-standard/toronto-greenstandard-version-3/

City of Toronto. (2020b). Development Charge Refund Program Version 3. Retrieved from:

https://www.toronto.ca/city-government/planning-development/official-plan-guidelines/toronto-greenstandard/toronto-green-standard-version-3/development-charge-refund-program-version-3/

City of Toronto. (2020c). Environmental Grants \& Incentives. Retrieved from: https://www.toronto.ca/servicespayments/water-environment/environmental-grants-incentives/

Census Mapper. (2016). Average Income Explorer. Retrieved from:

https://censusmapper.ca/maps/1535?index=3\#15/43.6470/-79.3929

[CMHC] Canada Mortgage and Housing Corporation. (2018a). Rental Construction Financing. National Housing Strategy. Retrieved from: https://www.cmhc-schl.gc.ca/en/nhs/rental-construction-financing-initiative

[CMHC] Canada Mortgage and Housing Corporation. (2018b). Co-Investment Fund - New Construction. Retrieved from: https://www.cmhc-schl.gc.ca/en/nhs/co-investment-fund---new-construction-stream

Conte, E. (2018). The Era of Sustainability: Promises, Pitfalls and Prospects for Sustainable Buildings and the Built Environment. Sustainability, 10, 2092. https://doi.org/10.3390/su10062092 
Cusa, M., Jackson, D. A., \& Mesure, M. (2015). Window collisions by migratory bird species: Urban geographical patterns and habitat associations. Urban Ecosystems, 18(4), 1427-1446. https://doi.org/10.1007/s11252015-0459-3 Ecological Economics. (n.d.). Retrieved February 19, 2020, from https://www.journals.elsevier.com/ecological-economics

Dale, A., Dushenko, W., \& Robinson, P. J. (2012). Urban Sustainability: Reconnecting Space and Place. University of Toronto Press, Scholarly Publishing Division.

Florida, R. (2017). The New Urban Crisis: How Our Cities Are Increasing Inequality, Deepening Segregation, and Failing the Middle Class-and What We Can Do About It (1 edition). Basic Books.

Freeman, B. (2015). The New Urban Agenda: The Greater Toronto and Hamilton Area. Dundurn.

Fuerst, F. (2009). Building momentum: An analysis of investment trends in LEED and Energy Star-certified properties. Journal of Retail \& Leisure Property, 8(4), 285-297. https://doi.org/10.1057/rlp.2009.18

Giddings, B., Hopwood, B., \& O’Brien, G. (2002). Environment, economy and society: Fitting them together into sustainable development. Sustainable Development, 10(4), 187-196. https://doi.org/10.1002/sd.199

Ghazoul, J., Burivalova, Z., Garcia-Ulloa, J., \& King, L. A. (2015). Conceptualizing Forest Degradation. Trends in Ecology \& Evolution, 30(10), 622-632. https://doi.org/10.1016/j.tree.2015.08.001

Hartmann, F. M. (1999). Nature in the City: Urban Ecological Politics in Toronto. Retrieved from: https://www.collectionscanada.gc.ca/obj/s4/f2/dsk1/tape9/PQDD 0023/NQ39270.pdf

Hulchanski, D. (2019). How Segregated is Toronto? Inequality, Polarization, and Segregation Trends and Processes. Neighbourhood Change Research Network, Factor-Inwentash Faculty of Social Work University of Toronto. Retrieved from:

https://www.ryerson.ca/content/dam/rcis/documents/Segregation_Trends in Toronto_Hulchanski_at_R yerson 14 Feb 2019 w Appendix.pdf

King et al. (2018). The City of Toronto Zero Emissions Buildings Framework. Retrieved from: https://www.toronto.ca/wp-content/uploads/2017/11/9875-Zero-Emissions-Buildings-FrameworkReport.pdf 
King Toronto Condos. (2019). Retrieved from: https://www.buzzbuzzhome.com/ca/king-toronto-condos

Lee, S. (2011). Aesthetics of Sustainable Architecture. 010 Publishers.

Lejeune, Z., Xhignesse, G., Kryvobokov, M., \& Teller, J. (2016). Housing quality as environmental inequality: The case of Wallonia, Belgium. Journal of Housing and the Built Environment, 31(3), 495-512. https://doi.org/10.1007/s10901-015-9470-5

Leslie, K. (2014). Activists say developers wield too much influence in municipal elections. Global News. Retrieved from: https://globalnews.ca/news/1613600/activists-say-developers-wield-too-much-influence-inmunicipal-elections/

Lindsay, L. (1973). THE PLURALIST PERSUASION IN AMERICAN DEMOCRATIC THOUGHT. Social and Economic Studies, 22(4), 479-513. JSTOR.

Maclaren, V .W. (1996). Urban Sustainability Reporting. The Journal of American Planning Association.

Madani, M. et al., (2019). Toronto Housing Market Analysis. Canadian Center for Economic Analysis and Canadian Urban Institute. Retrieved from: https://www.toronto.ca/legdocs/mmis/2019/ph/bgrd/backgroundfile124480.pdf

McKellar, J. (2017). The Toronto Housing Market - Can We Ever Get it Right? Retrieved from: http://schulich.yorku.ca/wp-content/uploads/2018/01/ULI-The-Toronto-Housing-Market.pdf

Melgar-Melgar, R. E., \& Hall, C. A. S. (2020). Why ecological economics needs to return to its roots: The biophysical foundation of socio-economic systems. Ecological Economics, 169, 106567. https://doi.org/10.1016/j.ecolecon.2019.106567

[MMAH] Ministry of Municipal Affairs and Housing. (2014). Provincial Policy Statement, 2014. Queen's Printer for Ontario. http://www.mah.gov.on.ca/Page10679.aspx\#Natural+Heritage

[MMAH] Ministry of Municipal Affairs and Housing. (2019). Proposed new regulation pertaining to the community benefit authority under the Planning Act. Retrieved from: https://ero.ontario.ca/notice/019-0183 
[NAIOP] The National Association of Industrial and Office Properties Research Foundation. (2007). Green Building Incentives That Work: A Look at How Local Governments Area Incentivizing Green Development. Retrieved from NAIOP Research Foundation website.

Ogden, L. E. (2014). Does Green Building Come up Short in Considering Biodiversity?: Focus on a growing concern. BioScience, 64(2), 83-89. https://doi.org/10.1093/biosci/bit019

Pickett, S. T. A., Cadenasso, M. L., \& Grove, J. M. (2004). Resilient cities: Meaning, models, and metaphor for integrating the ecological, socio-economic, and planning realms. Landscape and Urban Planning, 69(4), 369-384. https://doi.org/10.1016/j.landurbplan.2003.10.035

Planning Act, Revised Statutes of Ontario (1990, c. P-49). Retrieved from the Government of Ontario website: https://www.ontario.ca/laws/statute/90p13\#BK31

Raco, M. (2005). Sustainable Development, Rolled-out Neoliberalism and Sustainable Communities. Antipode, 37(2), 324-347. https://doi.org/10.1111/j.0066-4812.2005.00495.x

Reed, C., \& Lister, N.-M. (Eds.). (2014). Projective Ecologies (2nd New edition edition). ACTAR, Harvard Graduate School of Design.

Robert, K. W., Parris, T. M., \& Leiserowitz, A. A. (2005). What is Sustainable Development? Goals, Indicators, Values, and Practice. Environment: Science and Policy for Sustainable Development, 47(3), 8-21. https://doi.org/10.1080/00139157.2005.10524444

Rosen, G., \& Walks, A. (2014). Castles in toronto's sky: Condo-ism as urban transformation. Journal of Urban Affairs, 37. https://doi.org/10.1111/juaf.12140

Russ, N., Hanid, M., \& Kho, M. Y. (2018). Literature Review on Green Cost Premium of Sustainable Building Construction. International Journal of Technology, 9, 1715. https://doi.org/10.14716/ijtech.v9i8.2762

Shazmin, S. A. A., Sipan, I., Sapri, M., Ali, H. M., \& Raji, F. (2017). Property tax assessment incentive for green building: Energy saving based-model. Energy, 122, 329-339. https://doi.org/10.1016/i.energy.2016.12.078 
Statistics Canada. (2017). Toronto, C [Census subdivision], Ontario and Ontario [Province] (table). Census Profile. 2016 Census. Statistics Canada Catalogue no. 98-316-X2016001. Ottawa. Retrieved from:

https://www12.statcan.gc.ca/census-recensement/2016/dp-pd/prof/index.cfm?Lang=E

Turner, V. K. (2017). Obstacles to developing sustainable cities: The real estate rigidity trap. Ecology and Society, 22(2). https://doi.org/10.5751/ES-09166-220201

Vincent, D. (2018). Is another luxury condo project like the King Toronto development what the city needs right now? Toronto Star. Retrieved from: https://www.thestar.com/news/gta/2018/11/02/is-another-luxurycondo-project-like-the-king-toronto-development-what-the-city-needs-right-now.html

Wedding, G. C., \& Crawford-Brown, D. (2008). Improving the Link Between the LEED Green Building Label and a Building's Energy-Related Environmental Metrics. Journal of Green Building, 3(2), 85-105. https://doi.org/10.3992/igb.3.2.85

Wilson, E. O. (1984). Biophilia. Harvard University Press.

Winfield, M. (2003). Building Sustainable Urban Communities in Ontario: Overcoming the Barriers. The Pembina Institute. Retrieved from: https://www.pembina.org/reports/SGIII-three.pdf

Young, W., Hwang, K., McDonald, S., \& Oates, C. J. (2010). Sustainable consumption: Green consumer behaviour when purchasing products. Sustainable Development, 18(1), 20-31. https://doi.org/10.1002/sd.394

\section{Sources for Data Analysis Section}

The following websites were used to collect data about developers, including their years in operation, areas served, and headquarters.

UrbanToronto: https://urbantoronto.ca/

BuzzBuzzToronto: https://www.buzzbuzzhome.com/ca

ListWithUs: https://www.listwithus.ca/

CondoNow: https://condonow.com/

The City of Toronto Development Application Site:

http://app.toronto.ca/DevelopmentApplications/mapSearchSetup.do?action=init 